
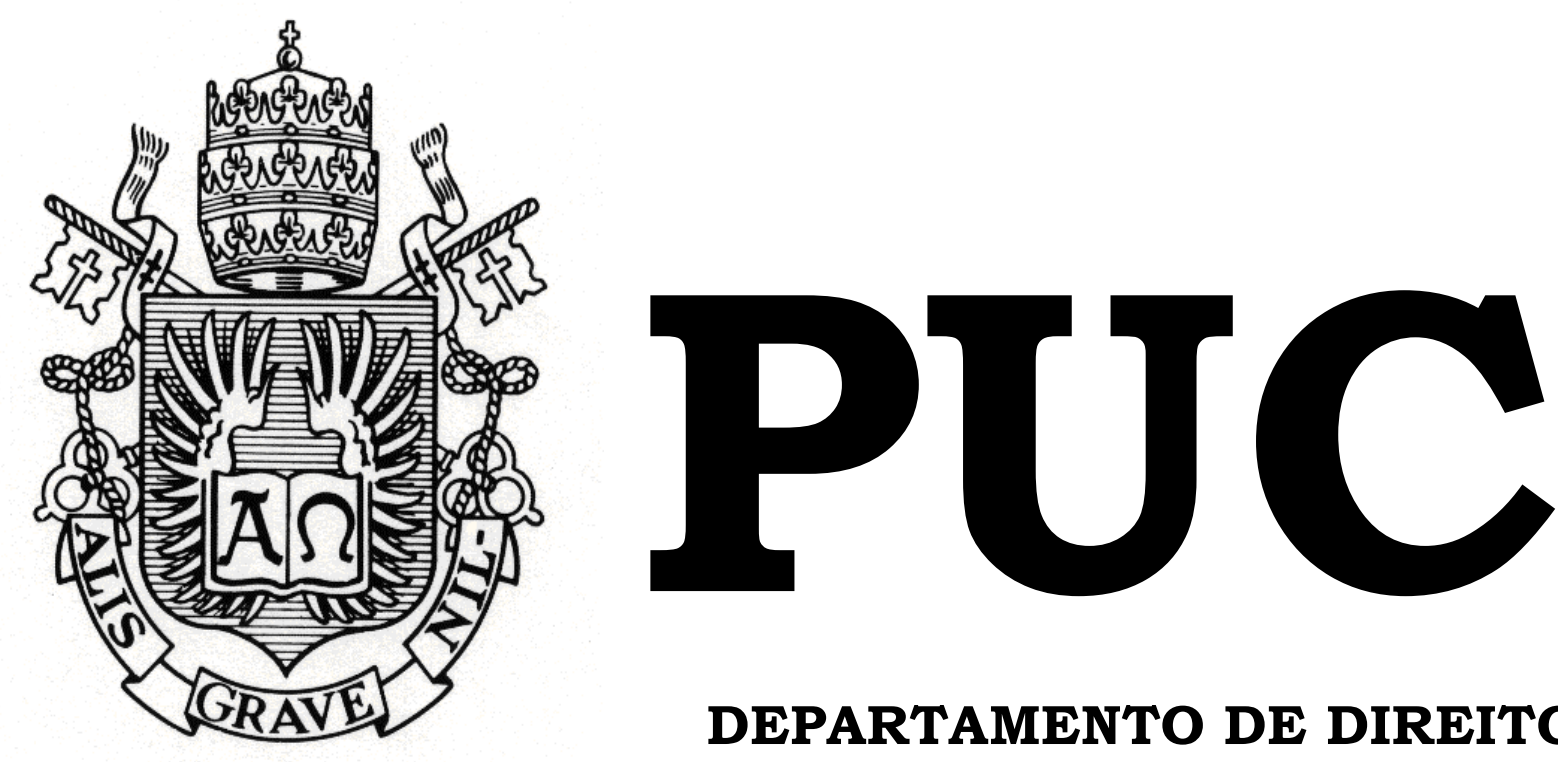

DEPARTAMENTO DE DIREITO

\title{
A NOVA LEI DE RECURSOS REPETITIVOS (LEI No $11.672 / 08)$ E SUAS MODIFICAÇÕES NO ÂMBITO DO PROCESSO CIVIL BRASILEIRO
}

\author{
por \\ NATÁLIA AGUIAR COELHO VALGODE \\ ORIENTADOR: MELVIN BADRA BENNESBY
}

2009.1

PONTIFÍCIA UNIVERSIDADE CATÓLICA DO RIO DE JANEIRO

RUA MARQUÊS DE SÃO VICENTE, 225 - CEP 22453-900

RIO DE JANEIRO - BRASIL 


\section{A NOVA LEI DE RECURSOS REPETITIVOS (LEI N. 11.672/08) E SUAS MODIFICAÇÕES NO ÂMBITO DO PROCESSO CIVIL BRASILEIRO}

por

NATÁlIA AGUIAR COELHO VALGODE

Monografia apresentada ao

Departamento de Direito da Pontificia Universidade

Católica do Rio de Janeiro (PUC-Rio) como requisito parcial para a obtenção do Título de Bacharel em Direito.

Orientador: Melvin Badra Bennesby 
Aos meus pais, meus avós e meu irmão (in memorian). 


\title{
RESUMO
}

\author{
VALGODE, Natália Aguiar Coelho. A NOVA LEI DE \\ RECURSOS REPETITIVOS (LEI No. 11.672/08) E SUAS \\ MODIFICAÇÕES NO ÂMBITO DO PROCESSO CIVIL \\ BRASILEIRO. PUC-Rio: 2009. Monografia.
}

Partindo da dogmática da Lei Processual Civil será feita uma análise da nova lei de recursos repetitivos (lei $n^{\circ}$. 11.672/08) atualmente inserida na dinâmica do Processo Civil Brasileiro, com ênfase nas conseqüências e modificações que serão geradas no procedimento de julgamento dos Recursos Especiais no âmbito do Superior Tribunal de Justiça.

\section{Palavras-chave:}

Recurso Especial - Recursos Repetitivos - Superior Tribunal de Justiça - Lei nº. 11.672/08 - Resolução no 7/2008 - Resolução

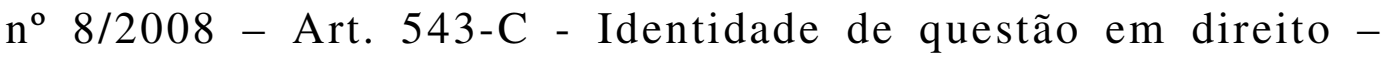
Amicus Curiae - Sobrestamento - Retenção - Processos Repetitivos - Questões Repetitivas - Recurso Representativo Suspensão - Efeitos do julgamento 


\section{SUMÁRIO}

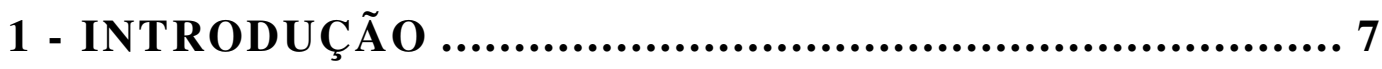

2 - O RECURSO ESPECIAL ....................................... 9

2.1 - HISTÓRICO .............................................. 9

2.2 - O PAPEL DO SUPERIOR TRIBUNAL DE JUSTIÇA ..12

2.3 - O RECURSO ESPECIAL E SEU PROCEDIMENTO....13

3 - A NOVA LEI No ${ }^{0}$ 11.672/08 .................................23

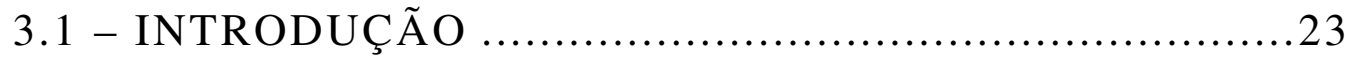

3.2 - DO PROCEDIMENTO DOS RECURSOS REPETITIVOS

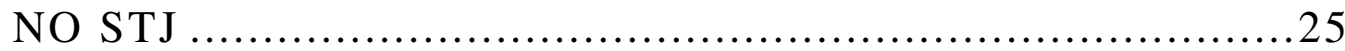

3.2 .1 - DA MULTIPLICIDADE DE RECURSOS E A IDÊNTICA QUESTÃO DE DIREITO ........................25

3.2 .2 - DA COMPETÊNCIA DE IDENTIFICAÇÃO DO RECURSO REPETITIVO E SUA ADMISSIBILIDADE ....29 3.2.3 - DO REQUERIMENTO DE INFORMAÇÕES E PARTICIPAÇÃO DE TERCEIROS ..............................30

3.2.4 - DA ATUAÇÃO DO MINISTÉRIO PÚBLICO ........33

3.2.5 - DO JULGAMENTO DOS RECURSOS REPETITIVOS .......................................... 34

3.2.6 - DA NECESSIDADE DE REGULAMENTAÇÃO ....38

3.2.7 - DA VIGÊNCIA DA LEI 11.672/08 ...................39

3.2 .8 - DO EFEITO SUSPENSIVO DO RECURSO ESPECIAL REPETITIVO E A INVIABILIDADE DE EXECUÇÃO PROVISÓRIA ......................................41

3.2.9 - DO RECURSO CONTRA DECISÃO QUE SUSPENDE O RECURSO ESPECIAL .........................43

4 - RESOLUÇÕES DO SUPERIOR TRIBUNAL DE JUSTIÇA E DO TRIBUNAL DE JUSTIÇA DO ESTADO DO RIO DE JANEIRO ...............................................47 
4.1 - RESOLUÇÃO Nº. 7/2008 DO SUPERIOR TRIBUNAL DE JUSTIÇA ........................................................ 47

4.2 - RESOLUÇÃO $\mathrm{N}^{\circ}$. 8/2008 DO SUPERIOR TRIBUNAL DE JUSTIÇA ....................................................4 48

4.3 - BREVES COMPARATIVOS DE PONTOS POLÊMICOS DAS RESOLUÇÕES .............................................53

4.3.1 - DA SUSPENSÃO DOS PROCESSOS ..................53

4.3.2 - EFEITO VINCULANTE DAS DECISÕES EM SEDE DE RECURSOS REPETITIVOS ?..........................55

4.4 - DA RESOLUÇÃO No. 3/2009 DO TRIBUNAL DE JUSTIÇA DO ESTADO DO RIO DE JANEIRO .................56

5 - ASPECTOS POLÊMICOS DA NOVA LEI E ANÁlISE JURISPRUDENCIAL ..............................................62

5.1 - DA (IM)POSSIBILIDADE DE DESISTÊNCIA DO RECURSO PARADIGMA …...............................62

5.2 - INCONSTITUCIONALIDADE DA LEI N ${ }^{\circ}$. 11.672/08? .66

5.3 - O RECURSO ESPECIAL REPETITIVO E AS AÇÕES COLETIVAS 67

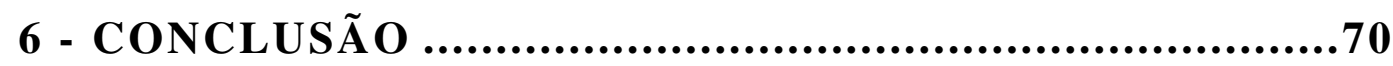

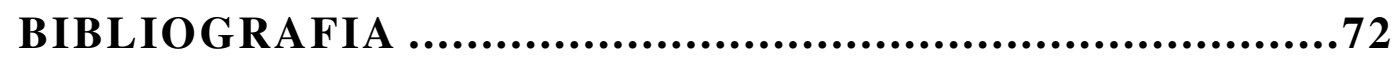

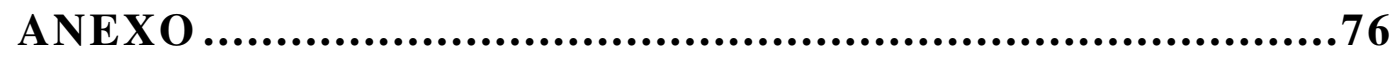




\section{LISTA DE ABREVIAÇÕES}

Art. - Artigo

CC - Código Civil

CF - Constituição Federal

CPC - Código de Processo Civil

REsp - Recurso Especial

RE - Recurso Extraordinário

STF - Supremo Tribunal Federal

STJ - Superior Tribunal de Justiça 


\section{1 - INTRODUÇÃO}

O presente trabalho objetiva analisar o recurso especial e as modificações trazidas pela Lei $\mathrm{n}^{\circ}$. 11.672/08, que alterou a sistemática deste recurso no Processo Civil Brasileiro.

O recurso especial é um recurso de natureza extraordinária que visa garantir e assegurar o respeito ao ordenamento jurídico pátrio infraconstitucional.

A Constituição Federal de 1988 criou o Superior Tribunal de Justiça (STJ), que possui a competência para julgar os recursos especiais. Anteriormente, o Supremo Tribunal Federal (STF) julgava nos recursos extraordinários tanto matéria infraconstitucional quanto constitucional, porém isso gerava uma grande sobrecarga, então criou-se o STJ para dividir essa competência. Com isso, o STF se tornou o guardião da Constituição Federal e o STJ passou a ser o guardião da legislação infraconstitucional federal.

Hoje, 20 anos após sua criação, o STJ sofre com a mesma sobrecarga que recaia sobre o STF, necessitando de medidas para diminuir o número de processos que chegam para sua análise.

A relevância deste trabalho consiste na análise da Lei $\mathrm{n}^{\circ}$. 11.672, de 08.05.08, publicada em 09.05.08, que pode ser uma das saídas para o problema supra citado, pois viabilizará a concretização da garantia fundamental da duração razoável do processo (Art. 5 , LXXVIII da Constituição Federal), voltada basicamente para a celeridade processual, buscando evitar o julgamento de inúmeros processos idênticos pelo STJ.

Em linhas gerais, a lei estabelece procedimento para o julgamento de recursos especiais repetitivos no âmbito do STJ, 
quando detectada a multiplicidade de recursos idênticos, baseados no mesmo fundamento de direito.

A Lei $n^{\circ}$. 11.672/08 acrescentou ao CPC o Art. 543-C, que estabelece o procedimento de julgamento em massa de recursos, o que permitirá, certamente, mais celeridade na prestação jurisdicional.

Na elaboração do trabalho será adotada a linha dogmática de pesquisa jurídica que "visa a propor estudos pormenorizados, aprofundados e verticalizados sobre temas de atualidade e relevância para melhor instrumentalização das práticas jurídicas” (Bittar 2009). Será realizada a análise da Lei $n^{\circ}$. 11.672/08 e das Resoluções $n^{\circ}$. 7/2008 e $n^{\circ}$. 8/2008 do STJ e da Resolução $n^{\circ} .03$ de 2009 da $3^{\text {a }}$ Vice Presidência do Tribunal de Justiça do Estado do Rio de Janeiro. Além disso, será feita pesquisa bibliográfica com livros e artigos jurídicos. Em seguida, será feito um estudo jurisprudencial das decisões mais importantes e recentes sobre o caso.

Esta será a análise deste trabalho monográfico. 


\title{
2 - O RECURSO ESPECIAL
}

\section{1 - HISTÓRICO}

Para entendermos melhor o tema a ser desenvolvido se faz necessária a análise de um breve histórico do recurso especial.

Os recursos excepcionais (especial e extraordinário) estão ligados de alguma maneira à forma federativa de Estado (Gleydison Kleber Lopes de Oliveira, Recurso Especial, RPC 9, 2002, Capítulo 2, pg. 123 apud Wambier, 2008).

\begin{abstract}
"Trata-se, a bem da verdade, de uma conseqüência inarredável ao sistema político nacional: a federação pressupõe uniformidade na aplicação e na interpretação das normas de direito federal em todo território, até mesmo por força da isonomia e da impessoalidade que deve presidir as relações entre Estado e particulares (arts. $5^{\circ}$, caput ${ }^{1}, 37$, caput ${ }^{2}$, e 150, II ${ }^{3}$ da Constituição Federal)." (Bueno 2008, P. 237)
\end{abstract}

Com relação ao seu surgimento, diz Teresa Arruda Alvim Wambier que:

\begin{abstract}
“(...) o recurso extraordinário surgiu no Brasil no momento histórico em que se estruturava o estado brasileiro, tendo-se, à época, instaurado o regime federativo.

E o recurso especial, na verdade, nada mais é do que uma parte do antigo recurso extraordinário. É extraordinário na parte que
\end{abstract}

\footnotetext{
1 "Art. $5^{\circ}$ Todos são iguais perante a lei, sem distinção de qualquer natureza, garantindo-se aos brasileiros e aos estrangeiros residentes no País a inviolabilidade do direito à vida, à liberdade, à igualdade, à segurança e à propriedade, nos termos seguintes:"

2 "Art. 37. A administração pública direta e indireta de qualquer dos Poderes da União, dos Estados, do Distrito Federal e dos Municípios obedecerá aos princípios de legalidade, impessoalidade, moralidade, publicidade e eficiência e, também, ao seguinte:"

3 "Art. 150. Sem prejuízo de outras garantias asseguradas ao contribuinte, é vedado à União, aos Estados, ao Distrito Federal e aos Municipios:

II - instituir tratamento desigual entre contribuintes que se encontrem em situação equivalente, proibida qualquer distinção em razão de ocupação profissional ou função por eles exercida, independentemente da denominação jurídica dos rendimentos, títulos ou direitos:"
} 
diz ofensa a lei federal." (T. A. Wambier, Recurso Especial, Recurso Extraordinário e Ação Rescisória 2008, P. 244)

O recurso especial é um recurso de natureza extraordinária que visa garantir e assegurar o respeito ao ordenamento jurídico pátrio infraconstitucional, além de ter o objetivo de uniformizar a interpretação do direito infraconstitucional brasileiro. Dessa forma diz Cássio Scarpinella Bueno que:

“O recurso extraordinário e o especial, (...), são 'recursos extraordinários', em contraposição aos chamados 'recursos ordinários'. Recursos extraordinários, neste contexto, são aqueles que têm por finalidade primeira a aplicação do direito positivo na espécie em julgamento, e não, propriamente, a busca da melhor solução para o caso em concreto. (...) A aplicação do direito positivo, mormente para fins de uniformização de sua interpretação, pressupõe que os fatos da causa estejam consolidados.” (Bueno 2008, P. 237)

Complementando essa idéia, Montovanni Colares

Cavalcanti, citado por Teresa Arruda Alvim Wambier diz que:

"Têm, os recursos especial e extraordinário, a função de preservar a ordem jurídica, evitando a dilaceração do sistema jurídico federal ou normativo federal, exercendo, assim, a sua função, que é a de tornar claras pautas de conduta." (Mantovanni Colares Cavalcanti, Recurso Especial e Extraordinário, São Paulo, Dialética, 2003, item 1.1.3.3, pg. 22,23 e 24 apud Wambier, 2008, P. 245)

Com relação ao surgimento do STJ, diz Roberto Carvalho de Souza em sua obra que:

"Coube à vigente Carta Política cometer, ao Supremo Tribunal Federal, a qualidade de Corte Constitucional. Mas a idéia de atribuição deste importante papel ao órgão julgador máximo, na estrutura do Poder Judiciário, não foi fruto exclusivo dos trabalhos da Assembléia Constituinte instalada a $1^{o}$ de fevereiro de 1987. Mesmo antes da Emenda Constitucional $n^{\circ} 1$, de 1969, um grupo de juristas já se reunia, na fundação Getúlio Vargas, no Rio de Janeiro, com o objetivo de se criar outro Tribunal, a latere do órgão de cúpula do Judiciário, de modo que, assim, a este fosse destinada a função de guardião da constituição. 
Dita exclusividade satisfaria, de um lado, o antigo anseio de dotar o novo órgão de característica de julgador eminentemente, como instância federal, de matéria infra constitucional, contribuindo ainda, de outro turno, para desafogar o Excelso Pretório da imensa sobrecarga que lhe assoberbava as pautas." (Souza 1997)

O surgimento do STJ foi dado a partir de uma crise. O volume de recursos extraordinários, no STF, aguardando julgamento era imenso. A quantidade de processos a serem julgados começava a assustar, sendo necessária a adoção de medidas para que as partes tivessem um julgamento célere, que obedecesse ao devido processo legal e à ampla defesa:

\begin{abstract}
"O número aproximado de dezessete mil recursos extraordinários interpostos até 1950 crescia para sessenta mil ao findar 1965, chegando em 1988, a perto de cento e vinte mil, de acordo com autorizada fonte.

Mas a seriíssima crise era tanto mais grave porque atingia, além do STF, também o Tribunal Federal de Recursos. Em 1974, este órgão, de acordo com notas de Theotonio Negrão, via-se as voltas com absurda sobrecarga: os treze magistrados que o integravam proferiam mais de mil votos.

Por outro lado, os Tribunais estaduais de justiça não se achavam distanciados do drama, nem a Justiça Federal constituía exceção a lastimosa regra." (Souza 1997)
\end{abstract}

A solução veio na Constituição de 1988, que promoveu uma reestruturação do judiciário, com o surgimento do STJ e com uma nova distribuição de competências.

"A Constituição da República, de 5 de outubro de 1988, atendeu aos reclamos: reestruturou o judiciário, promovendo, no acertado dizer de José Afonso da Silva, a redistribuição e a redefinição de competências e atribuições dos órgãos judiciários da União. Isso possibilitou o surgimento do STJ e do Recurso Especial, afastando do STF as causas atinentes a questões federais, porquanto o recurso extraordinário, desdobrando no então recém-instituído recurso especial, só pode, à luz do disposto no Art. 102, III, da Lei Maior, devolver ao Pretório Excelso matéria constitucional." (Souza 1997)

Hoje, o elevado número de recursos especiais ofertados passou a ser preocupante novamente. Então, começou-se a 
buscar regras que pudessem, ao mesmo tempo, garantir a celeridade processual, o contraditório e a ampla defesa, sem que se perdesse a qualidade das decisões e a análise a fundo de cada caso, respeitando sempre o devido processo legal. Diz a exposição de motivos da Lei Federal $n^{\circ}$. 11.672/08 ${ }^{4}$, que alterou o CPC Brasileiro (Lei $\mathrm{n}^{\circ}$. 5.869/73), acrescentando o Art. 543C:

“2. Sob a perspectiva das diretrizes estabelecidas para a reforma da Justiça, faz-se necessária a alteração do sistema processual brasileiro com o escopo de conferir racionalidade $e$ celeridade ao serviço de prestação jurisdicional, sem, contudo ferir o direito ao contraditório e à ampla defesa.

(...)

5. Somente em 2005, foram remetidos mais de 210.000 processos ao Superior Tribunal de Justiça, grande parte deles fundados em matérias idênticas, com entendimento já pacificado naquela Corte. Já em 2006, esse número subiu para 251.020, o que demonstra preocupante tendência de crescimento."

Nesse contexto, em 08.05.2008, foi promulgada a nova lei de recursos repetitivos (Lei Federal no ${ }^{\circ}$ 11.672/08), que será analisada neste trabalho e que traz importantes inovações nessa nova etapa da reforma do CPC Brasileiro, tentando solucionar o problema do julgamento dos recursos repetitivos, no âmbito do STJ.

\section{2 - O PAPEL DO SUPERIOR TRIBUNAL DE JUSTIÇA}

Fredie Didier Jr. e Leonardo José Carneiro da Cunha descrevem bem o papel do STJ:

"O Superior Tribunal de Justiça mantêm a função de interpretar a legislação infraconstitucional, corrigindo ilegalidades cometidas

\footnotetext{
${ }^{4}$ A íntegra da Exposição de Motivos da Lei pode ser encontrada no site da Câmara dos Deputados: http://www.camara.gov.br/sileg/integras/465291.pdf
} 
no julgamento das causas, em única ou última instância, pelos Tribunais Regionais Federais e pelos Tribunais de Justiça.

Nesse mister de interpretar e preservar a legislação infraconstitucional, insere-se uma outra função do STJ: uniformizar a jurisprudência nacional. Trata-se de função importantíssima, intimamente ligada com o principio da segurança jurídica. Ora, se ao STJ compete interpretar e preservar a legislação infraconstitucional, o julgamento que venha a ser proferido, conferindo interpretação a determinada norma federal, serve, a um só tempo, como corretivo da decisão impugnada $e$ elemento de uniformização da jurisprudência quanto a interpretação da referida norma.

Tudo isso significa que o STJ desempenha uma função paradigmática, na medida em que suas decisões servem de exemplo a ser seguido pelos demais Tribunais, com que obtém a uniformização da jurisprudência nacional. Na verdade tal função já era exercida pelo STF, antes do advento da Constituição Federal de 1988. (...)

Enfim, o STJ desempenha função primordial de interpretar $e$ preservar a legislação federal infraconstitucional, além de ter o papel de uniformizar a jurisprudência nacional quanto àquela mesma legislação, em decisões paradigmáticas. Essa função é exercida, essencialmente, mediante o julgamento de Recurso Especial (...).” (Didier Jr e Cunha 2009)

Com isso, vemos que o STJ tem a função de interpretar e preservar a legislação federal infraconstitucional, uniformizando a jurisprudência, em decisões paradigmáticas, sendo exercida, essencialmente, mediante o julgamento de recurso especial.

\section{3 - O RECURSO ESPECIAL E SEU PROCEDIMENTO}

Para que se possa analisar as mudanças ocorridas com o julgamento dos recursos repetitivos, se faz necessária a análise do "procedimento comum" dos recursos especiais.

A função do recurso especial é a manutenção da autoridade e unidade da lei federal. ${ }^{5}$ (Theodoro Júnior 2006, P. 710)

5 "A função do Recurso Especial, que antes era desempenhada pelo Recurso Extraordinário, é a manutenção da autoridade e unidade da lei federal, tendo em vista que na Federação existem múltiplos organismos 
Para apresentação do recurso especial deve ser obedecido um prazo de 15 dias determinado pelo Art. 508, do CPC, deve haver legitimidade das partes, interesse de quem apresenta, deve ser apresentado no vernáculo e deve ter forma escrita. Enfim, deve preencher todos os requisitos de interposição de qualquer recurso: requisitos intrínsecos (cabimento, legitimidade, interesse em recorrer, inexistência de fato impeditivo ou extintivo do direito de recorrer) e extrínsecos (tempestividade, regularidade formal e preparo).

É importante, ainda, tecer um breve comentário sobre o preparo no recurso especial. Anteriormente, para a interposição do recurso especial, havia a necessidade do recolhimento apenas do Porte de Remessa e Retorno dos autos, mas hoje, o STJ, pela Lei $n^{\circ}$. 11.636/07, Art. $6^{\circ}$, exige o pagamento de custas como requisito de admissibilidade para a interposição do recurso, devendo ser feito no Tribunal de origem no prazo de interposição do recurso, conforme o Art. 10 da referida lei.

Com relação a uma eventual irregularidade na representação processual, o Art. 13 do CPC prevê a suspensão do processo, porém, não há suspensão do processo com a interposição de recurso de natureza extraordinária, sendo considerado inexistente o recurso, em instância especial, de advogado que não possui procuração nos autos. Dessa forma dispõe a Súmula 115 , do STJ. ${ }^{6}$

Há também pressupostos específicos para a admissão e conhecimento do recurso especial. Que são: decisão proferida por Tribunal, matéria de direito federal, exaurimento das vias

judiciários encarregados de aplicar o direito positivo elaborado pela União." (Theodoro Júnior 2006, P. 710)

6 "Súmula 115 - Na instância especial é inexistente recurso interposto por advogado sem procuração nos autos" 
recursais ordinárias, prequestionamento e análise exclusiva de matéria de direito.

Com a análise do Art. 105, III $^{7}$, da Constituição Federal, pode-se verificar quais são as hipóteses de cabimento do recurso especial.

A causa que será debatida em sede de recurso especial precisa estar decidida. Mas o que o legislador quis dizer com isso? Diz Cassio Scarpinella que:

\begin{abstract}
“'Causas Decididas' querem significar antes de tudo, que a decisão que se submete ao recurso extraordinário e ao recurso especial são decisões que não comportam mais quaisquer outros recursos perante os demais órgãos jurisdicionais. Pressupõe-se para empregar expressão comuníssima 'exaurimento de instância'. É a diretriz segura da Súmula 281 do STF e da Súmula 207 do STJ (...).

Não só, contudo: a expressão causa decidida desempenha a mesma função que tradicionalmente exerceu a palavra 'prequestionamento', cunhada, o que tudo indica, a partir das previsões constantes das Constituições Federais de 1891 a 1946 e foi sob a égide da constituição de 1946 que duas importantes súmulas do STF sobre o assunto, a 282 e a 356, foram editadas -, que se referiam ao cabimento do recurso extraordinário, dentre outras hipóteses, quando se questionasse sobre a validade de lei federal em face da Constituição.

(...)

O prequestionamento, porém, diferentemente do que insinua o seu nome caracteriza-se pelo enfrentamento de uma dada tese de direito constitucional ou de direito infraconstitucional federal na decisão a ser recorrida, e não pelo debate ou pela suscitação da questão antes de seu proferimento. A palavra deve ser compreendida como a necessidade de o tema objeto do recurso haver sido examinado, enfrentado, decidido, pela decisão atacada. (...)" (Bueno 2008, P. 240/241)
\end{abstract}

\footnotetext{
7 “105 - Compete ao Superior Tribunal de Justiça (...)

III - julgar, em recurso especial, as causas decididas, em única ou última instância, pelos Tribunais Regionais Federais ou pelos Tribunais dos Estados, do Distrito Federal e Territórios, quando a decisão recorrida:

a) contrariar tratado ou lei federal, ou negar-lhes vigência;

b) julgar válido ato de governo local contestado em face de lei federal;

c) der a lei federal interpretação divergente da que lhe haja atribuído outro Tribunal."
} 
Com isso, vê-se que consiste em prequestionamento a expressa e prévia apreciação da matéria debatida em sede de recurso especial pelo Tribunal de origem. Caso a decisão seja omissa sobre o ponto que a parte deseja abordar em sede de recurso especial, devem ser opostos embargos de declaração, previstos no Art. 535, do CPC, pois o ponto omisso da decisão não pode ser objeto de recurso por não ter sido prequestionado. Esse é o teor da súmula 356 do $\mathrm{STF}^{8}$ e súmula 211 do $\mathrm{STJ}^{9}$.

Caso ainda permaneça omissa a decisão sobre o ponto que deveria estar prequestionado, deverá o recurso especial alegar ofensa ao Art. 535, do CPC, requerendo que os autos sejam novamente remetidos ao Tribunal a quo para que a questão seja apreciada e decidida pelo Tribunal.

O recurso especial só poderá ser interposto em face de decisões proferidas em única ou última instância. Isto é, em causas nas quais não seja possível a apresentação de mais nenhum recurso na instância ordinária, no caso, Tribunais de Justiça Estaduais, Tribunais Regionais Federais ou Tribunal de Justiça do Distrito Federal. Deve haver, portanto, o exaurimento das instâncias ordinárias. Não cabe recurso especial para o STJ das decisões proferidas pela Justiça Militar, Justiça do Trabalho ou Justiça Eleitoral.

No caso dos Juizados Especiais, é relevante citar que não cabe Recurso Especial da decisão das Turmas Recursais, como

\footnotetext{
8 "Súmula 356 - O ponto omisso da decisão, sobre o qual não foram opostos embargos declaratórios, não pode ser objeto de recurso extraordinário, por faltar o requisito do prequestionamento."

9 "Súmula 211 - Inadmissível recurso especial quanto à questão que, a despeito da oposição de embargos declaratórios, não foi apreciada pelo Tribunala quo."
} 
dispõe a Súmula 203 do $\mathrm{STJ}^{10}$.

O Art. 541 11 , caput, dispõe que o recurso especial é cabível nos casos previstos na Constituição Federal. Com isso, o recurso especial não pode ser admitido se não houver seu enquadramento nas hipóteses positivadas no Art. 105, III, da Constituição Federal.

A decisão recorrida, portanto, deve alternativamente: a) contrariar tratado ou lei federal, ou negar-lhes vigência; b) julgar válido ato de governo local contestado em face de lei federal; ou c) dar a lei federal interpretação divergente da que lhe haja atribuído outro Tribunal.

Com isso podemos ver que há muitas regras tentando restringir ao máximo a interposição do recurso especial.

O recurso especial deve ser interposto no prazo de 15 dias contados da data da publicação da decisão de única ou última instância pelos Tribunais Regionais Federais ou pelos Tribunais dos Estados, do Distrito Federal e Territórios. Podem ser inseridas aqui a regra do Art. 188 do CPC, no caso computarse-á em quádruplo o prazo para contestar e em dobro para recorrer quando a parte for a Fazenda Pública ou o Ministério Público, e a regra do Art. 191 do CPC, que dispõe que quando os litisconsortes tiverem diferentes procuradores, ser-lhes-ão contados em dobro os prazos para contestar, para recorrer e, de modo geral, para falar nos autos.

\footnotetext{
10 "Súmula 203 - Não cabe recurso especial contra decisão proferida por órgão de segundo grau dos juizados especiais”

11 “Art. 541. O recurso extraordinário e o recurso especial, nos casos previstos na Constituição Federal, serão interpostos perante o Presidente ou o Vice-Presidente do Tribunal recorrido, em petições distintas, que conterão:

I - a exposição do fato e do direito;

II - a demonstração do cabimento do recurso interposto;

III - as razões do pedido de reforma da decisão recorrida."
} 
Recebida a petição pela secretaria do Tribunal, será intimado o recorrido, abrindo-se vista, para apresentar contrarazões (Art. 542, do CPC). As contra-razões devem ser apresentadas no prazo de 15 dias. Aqui também podem ser aplicadas as regras dos Arts. 188 e 191, do CPC. Findo esse prazo, serão os autos conclusos para admissão ou não do recurso, no prazo de 15 (quinze) dias, em decisão fundamentada (Art. 541, $\S 1^{\circ}$, do CPC).

A admissibilidade do recurso é feita pelos Tribunais a quo em um primeiro momento. O recurso será analisado e caso preencha os requisitos de admissibilidade será admitido, sendo remetido para julgamento no STJ. Ao chegar ao referido Tribunal, sua admissibilidade será analisada novamente pelo Ministro Relator e caso seja submetido a julgamento, a Turma julgadora também poderá analisar os requisitos de admissibilidade do referido recurso.

Caso seja inadmitido o recurso especial, caberá o recurso de agravo de instrumento contra a decisão denegatória de recurso especial, conforme previsto no Art. 544, do CPC, que terá um prazo de 10 dias para sua interposição. No caso, interposto o recurso será aberto prazo para que o agravado se manifeste em contra-razões de agravo. Após a apresentação da referida peça de defesa, os autos serão remetidos pelo Tribunal a quo ao STJ para que o mesmo julgue o referido recurso.

O Ministro Relator, com base no agravo de instrumento pode: 1) admitir o recurso e dar provimento, reconhecendo a admissibilidade do recurso especial, para que o mesmo suba para ser julgado pelo STJ; 2) se o instrumento contiver os elementos necessários ao julgamento do mérito, determinar sua 
conversão, observando-se, daí em diante, o procedimento relativo ao recurso especial; 3) verificar que o acórdão recorrido está em confronto com a súmula ou jurisprudência dominante do Superior Tribunal de Justiça, conhecendo do agravo para dar provimento ao próprio recurso especial ou 4) rejeitar o agravo de instrumento. (Art. $\left.544, \S 3^{\circ}, \mathrm{CPC}\right)^{12}$

O recurso especial será recebido apenas em seu efeito devolutivo (Art. 542, §2 $2^{\circ}$, do CPC). No caso, não haverá efeito suspensivo da decisão.

Caso a parte entenda que seu recurso deva possuir o efeito suspensivo, tendo em vista que a decisão prolatada possa causar grave dano de difícil reparação, poderá requerer ao STJ por meio de medida cautelar. "Com efeito, presentes os requisitos do fumus boni iuris e
periculum in mora, conceder-se-á a suspensão dos efeitos da
decisão até a manifestação do Superior Tribunal de Justiça.
Excepcionalmente, estará assegurada a garantia constitucional
constante do Art. $5^{\circ}$, XXXV, da Constituição Federal, que objetiva
evitar a ocorrência de dano irreparável ou de difícil reparação."
(Serau Júnior e Reis $2009, \mathrm{P} .47$ )

Vale lembrar que a medida cautelar possui caráter excepcional, para conferir ao recurso especial o efeito suspensivo. Ainda mais se o juízo de admissibilidade ainda não tiver sido realizado pelo Tribunal a quo, pois nesses casos,

\footnotetext{
12 “Art. 544. Não admitido o recurso extraordinário ou o recurso especial, caberá agravo de instrumento, no prazo de 10 (dez) dias, para o Supremo Tribunal Federal ou para o Superior Tribunal de Justiça, conforme o caso.

(...)

§ 3 o Poderá o relator, se o acórdão recorrido estiver em confronto com a súmula ou jurisprudência dominante do Superior Tribunal de Justiça, conhecer do agravo para dar provimento ao próprio recurso especial; poderá ainda, se o instrumento contiver os elementos necessários ao julgamento do mérito, determinar sua conversão, observando-se, daí em diante, o procedimento relativo ao recurso especial."
} 
entende o STJ que o juízo positivo de admissão do apelo no Tribunal a quo é que inaugura a jurisdição do $\mathrm{STJ}^{13}$.

$\mathrm{O}$ Art. 542, $\$ 3^{\circ}$, do $\mathrm{CPC}$, dispõe que o recurso extraordinário, ou o recurso especial, quando interpostos contra decisão interlocutória em processo de conhecimento, cautelar, ou embargos à execução ficará retido nos autos e somente será processado se o reiterar a parte, no prazo para a interposição do recurso contra a decisão final, ou para as contra-razões.

Havendo interesse em destrancar o recurso, caso haja alegação de que a retenção irá lhe causar dano, também haverá a possibilidade da parte propor originariamente no STJ uma medida cautelar ou através de mera petição endereçada ao STJ, demonstrando esse prejuízo ou dano ${ }^{14}$. Com relação ao art. $542, \S 3^{\circ}$, do CPC, vale citar que:

13 "AGRAVO REGIMENTAL. CAUTELAR. LIMINAR. EFEITO SUSPENSIVO A RECURSO ESPECIAL QUE NÃO FOI OBJETO DE JUÍZO DE ADMISSIBILIDADE. EXCEPCIONALIDADE NÃO CARACTERIZADA. DISCUSSÃO RESTRITA À ANTECIPAÇÃO DA TUTELA RECURSAL. INEXISTENNCIA DE RISCO QUE JUSTIFIQUE SE PRECIPITAR AO JULGAMENTO DO MÉRITO PELO TRIBUNAL COMPETENTE.

1. Somente em casos excepcionais tem esta Corte admitido emprestar efeito suspensivo a recurso especial que não foi objeto de juízo de admissibilidade, quais sejam, evitar teratologias ou obstar os efeitos de decisão contrária à jurisprudência pacífica aqui assentada, situações não identificadas no caso em apreço.

2. Se não existe perigo de dano que justifique a alteração da antecipação da tutela recursal nos moldes em que concedida, mostra-se prudente aguardar o julgamento do mérito pelo Tribunal competente.

3. Agravo regimental desprovido."

(AgRg na MC 15.112/RJ, Rel. Ministro FERNANDO GONÇALVES, QUARTA TURMA, julgado em 02/04/2009, DJe 20/04/2009) (Grifou-se)

14 "AGRAVO DE INSTRUMENTO COM O OBJETIVO DE DESTRANCAR RECURSO ESPECIAL RETIDO NA ORIGEM ART. 542, § $3^{\circ}$ DO CPC.

1. A decisão que impõe a retenção do recurso especial tem nítida natureza interlocutória e conseqüentemente, não há erronia insuperável na interposição de agravo de instrumento desta decisão, máxime porque oscilante a jurisprudência do Eg. STJ no sentido do cabimento do recurso em exame, mediante a interposição de uma simples petição ou até mesmo de Medida Cautelar a indicar a admissão da fungibilidade recursal. 
"O texto legal objetiva evitar a proliferação de recursos em decisões interlocutórias, estendendo em demasia a solução do litígio, com repetidas análises sobre a mesma questão - de idêntico conteúdo jurídico. Além disso, o Art. 105 da Constituição autoriza o cabimento do recurso especial em face de acórdãos decididos em única ou última instância pelos Tribunais, o que afasta os acórdãos decorrentes de decisões interlocutórias." (Serau Júnior e Reis 2009, P. 46)

Há exceções a essa regra, conforme expõe José Edvaldo Albuquerque de Lima, citado na obra de Marco Aurélio Serau Júnior e Silas Mendes dos Reis:

\begin{abstract}
"No entanto, o recurso não comportará a forma retida nos casos de apreciação de antecipação de tutela e liminares, casos em que a retenção será passível de impugnação mediante agravo de instrumento ou ação cautelar inominada ao Tribunal competente, tendo em vista a possibilidade de prejuízo irreparável ao pólo da ação que sucumbirá a decisão prolatada.

o mesmo raciocínio emprega-se nos casos de discussão sobre competência, valor da causa, decreto de falência, indeferimento da entrada de litisconsorte e da isenção de pagamento das custas processuais (assistência judiciária gratuita, uma vez que em todos os casos pode haver prejuízo e dano irreparável, não se coadunando o ato com os valores e princípios que velam pela distribuição da justiça." (Lima, José Edvaldo Albuquerque de. Recurso Ordinário, extraordinário e especial. Rio de Janeiro: América Jurídica, 2006 APUD Serau Júnior e Reis 2009, P. 47)
\end{abstract}

Como o Recurso Especial não possui efeito suspensivo, mas meramente o devolutivo, sendo ele admitido, a decisão do Tribunal a quo terá eficácia, podendo haver a execução provisória (Art. 475-P e 475-O, §3º, ambos do CPC).

Esse capítulo tratou do procedimento que deve ser seguido pelos "recursos especiais comuns". Com o advento do Art. 543-C, do CPC, quando houver multiplicidade de recursos com fundamento em idêntica questão de direito, os recursos

2. Deveras, a regra genérica do Art. 522 do CPC e a especial do Art. 544 conspiram pela admissão do agravo quando retido o recurso especial de decisão que se alega potencialmente causadora de lesão irreparável. (...)” (AgRg no Ag 778.950/RS, Rel. Ministro LUIZ FUX, PRIMEIRA TURMA, julgado em 10/04/2007, DJ 07/05/2007 p. 280) 
serão processados de outra forma, que tenta conferir aos mesmos mais celeridade na tramitação sem que se percam as garantias constitucionais do devido processo legal e da ampla defesa. 


\section{3 - A NOVA LEI №. 11.672/08}

\section{1 - INTRODUÇÃO}

A Lei $n^{\circ}$. 11.672, de 08.05.08, publicada em 09.05.08, é um importante mecanismo para a concretização da garantia fundamental da duração razoável do processo (Art. $5^{\circ}$, LXXVIII da Constituição Federal) e do princípio da eficiência da administração pública (Art. 37, "caput" da Constituição Federal). Em linhas gerais, a lei estabelece procedimento para o julgamento de recursos especiais repetitivos no âmbito do Superior Tribunal de Justiça, quando detectada a multiplicidade de recursos com idêntico fundamento em questão de direito.

Quanto a sua origem, deve ser tecido um breve comentário sobre como a Lei 11.672/08 foi elaborada. O procedimento de aprovação da lei, da data em que o projeto foi apresentado ao plenário da Câmara dos Deputados até a data em que foi sancionado, foi inferior a um ano:

"A Lei 11.672/2008 teve origem em proposta do Poder Executivo, mediante envio ao Congresso Nacional da Mensagem 341, no dia 28.05.2007.

$\mathrm{Na}$ Câmara dos Deputados (Casa de origem), a proposta foi identificada como PL 1.213/2007.

$O$ relator do projeto foi o deputado Maurício Rands, do PT-PE, que teve seu relatório aprovado, à unanimidade, no dia 09.10.2007, o mesmo se dizendo em relação ao relatório final do projeto, lavra do Deputado Mendes Ribeiro Filho, do PMDB/RS, aprovado pela CCJC da Câmara dos Deputados no dia 13.11.2007. No Senado Federal, o PL 1.213/2007 foi identificado como PLC 117/2007, sendo designada relatora a Senadora Serys Slhessarenko, do PT/MT.

As Emendas de alterações 1 e 2, sugeridas pelo Senador Flexa Ribeiro, do PSDB/PA, foram rejeitadas pela CCJC do Senado, em reunião ocorrida no dia 19.03.2008. Na mesma data, o relatório apresentado pela Senadora Serys Slhessarenko foi aprovado, com as emendas de redação que menciona.

No dia 09.04.2008, o PLC 117/2007 foi aprovado no plenário do Senado Federal, seguindo a sanção presidencial no dia 17.04.2008. 
Com base nestas informações, verificamos que, da data em que o projeto foi apresentado ao plenário da Câmara dos Deputados (30.05.2007) até a data em que foi sancionado (08.05.2008), transcorreu-se um período de tempo inferior a um ano, o que se afigura bom e até incomum para o ritmo dos trabalhos legislativos do Congresso Nacional." (Tavares Junior 2009, P. 191)

A edição da referida lei acresce ao CPC o Art. 543-C, o qual estabelece o procedimento de julgamento em massa de recursos, o que permitirá, certamente, uma maior celeridade na prestação jurisdicional, nos processos em trâmite no STJ e nos Tribunais de $2^{\circ}$ Grau. Diz o Art. 543-C, do CPC:

"Art. 543-C: Quando houver multiplicidade de recursos com fundamento em idêntica questão de direito, o recurso especial será processado nos termos deste artigo.

$\S 1^{\circ}$ Caberá ao Presidente do Tribunal de origem admitir um ou mais recursos representativos da controvérsia, os quais serão encaminhados ao Superior Tribunal de Justiça, ficando suspensos os demais recursos especiais até o pronunciamento definitivo do Superior Tribunal de Justiça.

$\S 2^{\circ}$ Não adotada a providência descrita no $\$ 1^{\circ}$ deste artigo, o relator no Superior Tribunal de Justiça, ao identificar que sobre a controvérsia já existe jurisprudência dominante ou que a matéria já está afeta ao colegiado, poderá determinar a suspensão, nos Tribunais de segunda instância, dos recursos nos quais a controvérsia esteja estabelecida.

$\S 3^{\circ} \mathrm{O}$ relator poderá solicitar informações, a serem prestadas no prazo de quinze dias, aos Tribunais federais ou estaduais a respeito da controvérsia.

$\S 4^{\circ}$ O relator, conforme dispuser o regimento interno do Superior Tribunal de Justiça e considerando a relevância da matéria, poderá admitir manifestação de pessoas, órgãos ou entidades com interesse na controvérsia.

$\S 5^{\circ}$ Recebidas as informações e, se for o caso, após cumprido o disposto no $\$ 4^{o}$ deste artigo, terá vista o Ministério Público pelo prazo de quinze dias.

$\S 6^{\circ}$ Transcorrido o prazo para o Ministério Público e remetida cópia do relatório aos demais Ministros, o processo será incluído em pauta na seção ou na Corte Especial, devendo ser julgado com preferência sobre os demais feitos, ressalvados os que envolvam réu preso e os pedidos de habeas corpus.

$\S 7^{\circ}$ Publicado o acórdão do Superior Tribunal de Justiça, os recursos especiais sobrestados na origem:

I - terão seguimento denegado na hipótese de o acórdão recorrido coincidir com a orientação do Superior Tribunal de Justiça; ou 
II - serão novamente examinados pelo Tribunal de origem na hipótese de o acórdão recorrido divergir da orientação do Superior Tribunal de Justiça.

$\S 8^{\circ} \mathrm{Na}$ hipótese prevista no inciso II do $\$ 7^{\circ}$ deste artigo, mantida a decisão divergente pelo Tribunal de origem, far-se-á o exame de admissibilidade do recurso especial.

$\S 9^{\circ}$ O Superior Tribunal de Justiça e os Tribunais de segunda instância regulamentarão, no âmbito de suas competências, os procedimentos relativos ao processamento e julgamento do recurso especial nos casos previstos neste artigo."

Esse artigo será objeto desta monografia. Além do mesmo, será analisada a Resolução $n^{\circ}$. 8/2008 do STJ e a Resolução no. 3 de 2009 do Tribunal de Justiça do Estado do Rio de Janeiro, bem como a revogada Resolução nº 7/2008 do STJ, e as transformações que o mesmo traz para a sistemática dos recursos especiais que se enquadram em seu molde.

\section{2 - DO PROCEDIMENTO DOS RECURSOS REPETITIVOS NO STJ}

O procedimento dos recursos especiais repetitivos é definido pelo Art. 543-C, do CPC. No âmbito do STJ, é regulado pela Resolução $\mathrm{n}^{\circ}$. 8/2008 do STJ. O Tribunal de Justiça do Rio de Janeiro, por sua vez, em 07.05.09, editou a Resolução $n^{\circ}$. 3, de 2009, que regula o trâmite desses recursos no Tribunal Fluminense.

\subsection{1 - DA MULTIPLICIDADE DE RECURSOS E A IDÊNTICA QUESTÃO DE DIREITO}

Do caput do Art. 543-C, do CPC, podemos extrair dois requisitos para sua aplicação, são eles: a multiplicidade de recursos e idêntica questão de direito. 
No que se refere ao primeiro requisito, não há determinação legal quanto ao número mínimo de casos para se enquadrar no artigo acima aludido.

Já no tocante à idêntica questão de direito, podemos afirmar que são aquelas questões onde não se deve levar em consideração a discussão de fatos, mas puramente de direito. Nesse sentido dispõe Alexandre de Freitas Câmara:

\footnotetext{
"Ao nosso juízo, é preciso considerar que a regulamentação estabelecida pela Art. 543-C (criado pela Lei $n^{o}$. 11.672/08) e por seus parágrafos se aplica tão-somente às chamadas 'demandas repetitivas', assim consideradas aquelas demandas que são rigorosamente idênticas a incontáveis outras, distinguindo-se apenas por seus elementos subjetivos, mas sendo idênticas as causas de pedir e pedidos." (Câmara 2008, P. 125)
}

Portanto, será aplicado o procedimento do julgamento dos recursos repetitivos apenas no caso de demandas com discussões exatamente iguais, sendo diferenciadas apenas por seus elementos subjetivos, devendo possuir as causas de pedir e pedidos idênticas.

Segundo Marco Aurélio Serau Júnior e Silas Mendes dos Reis, a identificação desses recursos representativos deve observar dois aspectos, um quantitativo e outro qualitativo:

\footnotetext{
"O primeiro aspecto, quantitativo, diz respeito a necessidade de a questão de direito repetir-se em número elevado de demandas. Essa avaliação da pletora de recursos especiais sobre determinada matéria deve considerar os recursos já existentes e, de acordo com as informações prestadas pelas instâncias ordinárias, também o número de processos que porventura possam ensejar a interposição de recurso especial.

Caso a questão a ser apreciada na superior instância seja singular, quer dizer não se repita em outros feitos ou isso ocorra apenas em uma pequena medida, cremos ser o caso de apreciação do recurso especial pela sistemática processual anterior, em que não se aplica o regime da suspensão ao apelo excepcional.

Outrossim, cumpre examinar que a identificação do recurso representativo ainda obedece a um critério superior, qualitativo.
} 
Inicialmente a esse respeito, verifica-se que a questão repetitiva deve ser exclusivamente de direito, como, ademais, impõe a própria posição especial das Cortes Superiores (...).

Em termos procedimentais, deve-se escolher o recurso que traga mais e melhores argumentos a respeito da interpretação a ser dada à legislação federal sob apreciação do Superior Tribunal de Justiça (conforme disposto no Art. $1^{o} \$ 1^{o}$, da Resolução 8 do STJ), preferencialmente um processo de cada Ministro Relator." (Serau Júnior e Reis 2009, P. 51)

Dessa forma, com relação ao aspecto quantitativo, deverá o caso ser repetido em um grande número de recursos. Caso contrário, se for singular, deverá a questão ser apreciada pelo "procedimento comum" do recurso especial.

No aspecto qualitativo, deve a questão a ser discutida em sede de recurso especial versar unicamente sobre matéria de direito. É importante relembrar que isso já é requisito para a interposição de recursos para as instâncias superiores, onde não se admite nova discussão dos fatos e nem uma nova análise das provas $^{15}$.

No caso devem ser escolhidos os recursos que tragam mais e melhores argumentos a respeito da interpretação a ser dada à legislação federal.

Assim sendo, no tocante à quantidade de recursos, poderá ser escolhido mais de um recurso especial representativo da controvérsia, se for necessário, podendo ser admitidos recursos de partes diferentes envolvidas na demanda. Nesse sentido, diz Eduardo Talamini:

\footnotetext{
"Cabe atentar para a noção de recurso 'representativo da controvérsia'. Caberá ao órgão a quo selecionar um ou mais processos em que os subsídios instrutores (jurídicos e fáticos) reunidos permitam ao STJ a mais precisa percepção possível não apenas da questão de direito cuja relevância há de se aferir, como também do conflito em que ela se insere. Sendo assim, a adequada representação da controvérsia não depende apenas da peça recursal, ainda que esse seja o mais importante elemento. Outros
}

15 "Súmula 7 - A pretensão de simples reexame de prova não enseja recurso especial" 
atos do processo serão também muito úteis para tanto (as contrarazões ao recurso, a decisão recorrida, outras petições anteriores...). Então, o órgão a quo deverá considerar a qualidade desses vários atos, e não apenas propriamente a do recurso. Evidentemente, é possível que um mesmo e único processo não reúna todas as peças mais adequadas à representação da controvérsia. Nessa hipótese, o órgão a quo deverá encaminhar tantos recursos em diferentes processos quanto seja necessário ( $p$. ex., um por ter a peça recursal mais clara e precisa, outro pela qualidade das contra razões, um terceiro por conter acórdão melhor fundamentado etc.)." (Talamini 2008)

Podemos ver, portanto, que o citado autor acredita que possa ser selecionado mais de um recurso representativo, com pontos de vista diferentes, uns recorrendo no sentido de uma tese e outros de outra tese. O recurso paradigma deverá conter todos os fundamentos necessários à compreensão integral da questão de direito, não dependendo apenas da peça recursal, mas também de outros instrumentos, como a decisão recorrida, as contra-razões entre outras peças que possam ajudar na análise da controvérsia.

Nesse mesmo sentido Teresa Arruda Alvim Wambier diz que a norma não leva em conta critérios como a quantidade de litisconsortes, a natureza individual ou coletiva da ação, etc. Os recursos devem ser relacionados a um determinado problema jurídico, não se exigindo que tenham sido todos interpostos para que se acolha uma mesma tese. É importante, no entanto, que, havendo recursos em sentido favorável e contrário a uma dada orientação, sejam selecionados recursos que exponham, por inteiro, ambos os pontos de vista." (Wambier e Medina, P. 217)

Deve ser observado o critério de escolha dos recursos que tragam mais e melhores argumentos a respeito da interpretação a ser dada à legislação federal, pois a escolha de um recurso ruim ou mal fundamentado pode trazer prejuízos aos recorrentes que tiveram seus recursos sobrestados, pois o 
julgamento destes recursos paradigmas será aplicado a todos os outros fundados em idêntica questão de direito.

\title{
3.2.2 - DA COMPETÊNCIA DE IDENTIFICAÇÃO DO RECURSO REPETITIVO E SUA ADMISSIBILIDADE
}

Em relação à forma como o Art. 543-C, do CPC, será aplicado, devemos nos ater ao que dispõe os respectivos $\S \S 1^{\circ}$ e $2^{\circ}$, que atribuem ao Presidente do Tribunal ou Vice-Presidente, conforme dispuser o respectivo regimento interno, o dever de admitir os recursos que representam a controvérsia e encaminhá-los para o STJ. Nesse sentido, dizem Marco Aurélio Serau Júnior e Silas Mendes dos Reis:

\begin{abstract}
"A competência para identificar o recurso representativo é do Presidente ou Vice-Presidente, conforme dispuser o respectivo regimento interno, do Tribunal recorrido. A este caberá admitir um ou mais recursos representativos da controvérsia, os quais serão encaminhados ao Superior Tribunal de Justiça, ficando os demais suspensos até o pronunciamento definitivo do Tribunal (conforme disposto no Art. $1^{\circ}$, caput, da Resolução 8 do STJ) Caso não seja admitido o recurso pelo Tribunal de origem, o Ministro Relator, já na esfera de competência do Superior Tribunal de Justiça e ao identificar que sobre a controvérsia nele versada já existe jurisprudência dominante ou que a matéria já está afetada a um dos órgãos colegiados, poderá determinar a suspensão, nos Tribunais de segunda instância, dos recursos nos quais aquela controvérsia esteja estabelecida." (Serau Júnior e Reis 2009, P. 52)
\end{abstract}

A competência de selecionar o recurso paradigma é do Presidente do Tribunal a quo. Sendo selecionado o recurso piloto, ficarão suspensos os recursos especiais que versem sobre idêntica questão de direito, até o julgamento daquele no $\mathrm{STJ}^{16}$.

\footnotetext{
16 "PROCESSUAL CIVIL - RECURSO ESPECIAL - INTERRUPÇÃO DA PRESCRIÇÃO -CITAÇÃO EDITALÍCIA - RECURSO REPETITIVO SUSPENSÃO - ART. 543-C DO CPC - RECURSO ESPECIAL SOBRESTADO. DECISÃO

Vistos.
} 
Caso a função de caracterização da repetitividade não seja exercida pelo Presidente do Tribunal de origem, o relator do recurso no STJ, verificando que já existe jurisprudência dominante ou que a matéria já está afetada a um dos órgãos do STJ, poderá determinar a suspensão, nos Tribunais de segunda instância, dos recursos que tenham controvérsia sobre idêntica questão de direito.

\subsection{3 - DO REQUERIMENTO DE INFORMAÇÕES E PARTICIPAÇÃO DE TERCEIROS}

Caracterizada a repetitividade, o relator poderá solicitar informações, a serem prestadas no prazo de quinze dias, aos Tribunais Federais, Tribunais de Justiça Estaduais ou ao Tribunal de Justiça do Distrito Federal, a respeito da controvérsia (Art. 543-C, $\S 3^{\circ}$, do CPC).

As informações que podem ser requeridas aos Tribunais Federais ou de Justiça referem-se a dados estatísticos ou mesmo

Cuida-se de recurso especial que tem por objeto a discussão sobre possibilidade de interrupção da prescrição por meio de citação por edital em ação de execução fiscal.

$\dot{E}$, no essencial, o relatório.

A matéria objeto do recurso especial insere-se nos moldes de processo afeto à Corte Especial e às Seções do Superior Tribunal de Justiça, especificamente o REsp 999.901, para os fins do que dispõe o art. 543-C do $C P C$.

Nessa circunstância, o presente recurso tem natureza repetitiva, porquanto há multiplicidade de espécies recursais, com fundamento em idêntica questão de direito. Dessa forma, impõe-se sua suspensão, em obediência ao § 10 do art. 543-C: "Caberá ao presidente do tribunal de origem admitir um ou mais recursos representativos da controvérsia, os quais serão encaminhados ao Superior Tribunal de Justiça, ficando suspensos os demais recursos especiais até o pronunciamento definitivo do Superior Tribunal de Justiça. (Incluído pela Lei $n^{o} 11.672$, de 2008)." Devido tal fundamento e pelo que dispõe o art. 20 , $\$ 2 o$, da Resolução $n$. $8 / 2008$, entendo ser o caso de sobrestar este recurso especial.

Ante o exposto, determino o sobrestamento deste recurso, até o julgamento final do processo paradigma pelo órgão competente do Superior Tribunal de Justiça.

Publique-se. Intimem-se." (REsp $n^{o}$. 950.884 - MG, Ministro Humberto Martins, Publicado em 08.05.2009). 
ao conteúdo de direito tratado nos recursos representativos. (Serau Júnior e Reis 2009, P. 56)

Outro ponto que merece destaque diz respeito ao $\S 4^{\circ}$, do art. 543-C, do CPC, que possibilita a participação da figura do "amicus curiae", permitindo que terceiros passem a integrar a demanda, para discutir objetivamente teses jurídicas que vão afetar a sociedade de alguma forma, sempre levando em consideração a relevância da matéria. Nesse sentido, assevera o autor Eduardo Talamini:

\begin{abstract}
“(...) Essa regra é de todo justificável quando se considera que o julgamento do recurso amostra é apto a ter relevância que vai além do processo em que realizado. A lei não especifica qual o requisito para a participação dos terceiros. Uma possivel interpretação é no sentido de que tal regra equivalha àquela que, nos processos e incidentes de controle direto de constitucionalidade, permite a manifestação de terceiros que demonstrem uma especial legitimidade e qualificação para colaborar com subsídios na definição da questão, como amicus curiae (Lei 9.868/1999, Art. $7^{\circ}, \S 2^{\circ}$; Lei 11.417/2006, Art. 3 ${ }^{\circ}, \S$ $2^{\circ} ; \quad$ CPC, Art. 482, $\left.\S 3^{\circ}\right)$. Outra exegese, mais calcada na literalidade do Art. 543-C, $\S 4^{o}$, é no sentido de que basta à 'pessoa, órgão ou entidade' demonstrar seu "interesse na controvérsia". A solução mais adequada parece ser intermediária entre essas duas concepções. Por um lado, a aferição da aptidão para intervir não pode ser tão objetiva, fundada estritamente na qualidade da contribuição que o terceiro está potencialmente apto a dar, como ocorre nos processos e incidentes de controle de constitucionalidade. Mas, por outro, também não parece viável admitir no processo, como amicus curiae, todo aquele que apenas demonstre ser parte em outro processo em que há recurso sobre a mesma questão. Assim, em princípio, aqueles que comprovarem essa condição de parte em outros processos podem ser admitidos como colaboradores de Corte, desde que demonstrem que têm algum argumento útil, algum subsídio relevante para acrescentar à discussão já instaurada.” (Talamini 2008)
\end{abstract}

A posição adotada pelo aludido autor parece ser a mais coerente a respeito da aplicação da nova lei. Não basta apenas que a pessoa demonstre que possui uma demanda sobrestada, por possuir idêntica questão de direito a do recurso paradigma, para que se admita sua participação como "amicus curiae". Não pode ser o requisito tão objetivo. Acreditamos que devem ser 
admitidos os terceiros que, além de comprovarem que são parte em outros processos, possam contribuir com argumentos úteis para o julgamento do acórdão paradigma.

Caso contrário, o julgamento do recurso paradigma ficará inviável, pois serão tantas peças a serem analisadas pelo Ministro Relator e pelo órgão julgador que o julgamento dos mesmos levará muito mais tempo e não terá a qualidade que se espera.

Complementando essa opinião, mostra-se relevante citar Daniel Moura Nogueira que diz que:

“A permissão pela intromissão dessa figura interventiva (amicus curiae) tem, nada mais, que duas projeções, nas quais a primeira com maior afinco é tornar a situação isenta de parcialidade ou questionamento, pois, ninguém poderá alegar julgamento à revelia de interessados, uma vez a possibilidade da intervenção. A segunda, cremos permitir, na realidade a participação de interessados com o desiderato de evitar aplicação injusta, ou seja, uma forma de filtrar os casos que se encontram na fila para obter o mesmo fim - o mesmo teor de julgamento." (Nogueira 2008, P. 240)

A finalidade da permissão do instituto do "amicus curiae" seria tornar o julgamento do recurso representativo da controvérsia isento de parcialidade e a participação de interessados teria também a intenção de evitar aplicação injusta, ou seja, para que se possa ter o mesmo teor de julgamento.

Esse é um dos mecanismos que a nova lei de recursos repetitivos traz, para que não sejam desrespeitados os princípios do contraditório e da ampla defesa, pois terceiros poderão intervir e ajudar na elucidação da matéria repetitiva discutida no recurso paradigma, auxiliando dessa forma no julgamento da questão. 


\subsection{4 - DA ATUAÇÃO DO MINISTÉRIO PÚBLICO}

O Art. 534-C, $\S 5^{\circ}$, dispõe sobre a atuação do Ministério Público, que terá vista dos autos por 15 dias após o cumprimento do disposto no $\S 4^{\circ}$.

O Art. 82, III, do $\mathrm{CPC}^{17}$ determina a intervenção do Ministério Público nas demais causas em que haja interesse público evidenciado pela natureza da lide ou qualidade da parte, que é o caso dos recursos repetitivos.

O Ministério Público, no caso, estará atuando como fiscal da lei, por isso se faz necessária sua intervenção. Por outro lado, Marco Aurélio Serau Júnior e Silas Mendes dos Reis afirmam que sua ausência acarretaria a nulidade:

\footnotetext{
"Tratando-se de julgamento de recurso especial representativo de demanda que se reproduz em múltiplos outros processos da esfera de competência do Superior Tribunal de Justiça, temos que, apenas e exclusivamente por este fato, já estaria configurada a hipótese do interesse público evidenciado pela natureza da lide a justificar a intervenção ministerial.

(...)

Diante disso, a inexistência de participação do Ministério Público no julgamento do recurso representativo acarretará a nulidade prevista no Art. 246, caput, do Código de Processo Civil." (Serau Júnior e Reis 2009, P. 58)
}

Portanto, a posição mais correta a ser adotada é a de considerar que deverá o Ministério Público ser intimado, na qualidade de custos legis, sob pena da nulidade prevista no Art. 246, do $\mathrm{CPC}^{18}$.

\footnotetext{
17 "Art. 82. Compete ao Ministério Público intervir:

I - nas causas em que há interesses de incapazes;

II - nas causas concernentes ao estado da pessoa, pátrio poder, tutela, curatela, interdição, casamento, declaração de ausência e disposições de última vontade;

III - nas ações que envolvam litígios coletivos pela posse da terra rural $e$ nas demais causas em que há interesse público evidenciado pela natureza da lide ou qualidade da parte."

18 "Art. 246. É nulo o processo, quando o Ministério Público não for intimado a acompanhar o feito em que deva intervir.
} 


\subsection{5 - DO JULGAMENTO DOS RECURSOS REPETITIVOS}

O $\S 6^{\circ}$, do Art. 543-C, do CPC dispõe que transcorrido o prazo para a manifestação do Ministério Público e remetida cópia do relatório aos demais Ministros, o processo será incluído em pauta na Seção ou na Corte Especial, devendo ser julgado com preferência sobre os demais feitos, ressalvados os que envolvam réu preso e os pedidos de habeas corpus. Nesse sentido, diz Daniel Moura Nogueira:

\footnotetext{
"Sendo o caso de julgamento uno para vários casos análogos, terá o processo representativo dos recursos, preferência de julgamento sobre os demais recursos isolados, sem preterir, o que fica como ressalva da lei, os remédios fundamentais como o habeas corpus, e nos casos de réu preso." (Nogueira 2008, P. 241)
}

De acordo com o $\$ 7^{\circ}$, do Art. 543-C, do CPC, publicado o acórdão do Superior Tribunal de Justiça, os recursos especiais sobrestados na origem (I) terão seguimento denegado na hipótese de o acórdão recorrido coincidir com a orientação do Superior Tribunal de Justiça; ou (II) serão novamente examinados pelo Tribunal de origem na hipótese de o acórdão recorrido divergir da orientação do Superior Tribunal de Justiça (Art. 543-C, $\S 7^{\circ}$, do CPC).

Com relação ao inciso I, do $\S 7^{\circ}$ do Art. 543-C, do CPC, defende Daniel Moura Nogueira:

\footnotetext{
"Isso se dará por uma questão muito simples e óbvia, pois se a sistemática existe para julgamento uno dos casos análogos, o Tribunal de origem apenas e tão somente aplicará à impugnação do acórdão por ele proferido, a posição a que chegou a Corte
}

Parágrafo único. Se o processo tiver corrido, sem conhecimento do Ministério Público, o juiz o anulará a partir do momento em que o órgão devia ter sido intimado." 
Superior. Logo a questão sendo já resolvida no mesmo sentido do acórdão guerreado do Tribunal a quo, impõe-se por conseqüência lógica a sua permanência. Assim, o seguimento tornar-se-á inócuo.

Chegando a esse primeiro resultado, nada diz o artigo, mas extrai-se dos seus próprios termos que correrá ordinariamente o prazo de 15 dias para impugnação por outro recurso, caso caiba, o que, passando esse prazo terá por transitada em julgado a decisão do acórdão a quo." (Nogueira 2008, P. 241)

Com isso, na hipótese de o acórdão recorrido coincidir com a orientação do Superior Tribunal de Justiça, deverá o Tribunal de origem aplicar a decisão do recurso paradigma, denegando seguimento ao recurso, pois as decisões têm o mesmo posicionamento, não havendo a necessidade do recurso especial que ficou sobrestado ir a julgamento no STJ.

Nesse caso, é interessante ressaltar a posição adotada por Daniel Moura Nogueira de que aplicada a decisão do STJ no recurso sobrestado, no caso da mesma coincidir com a decisão recorrida, correrá ordinariamente o prazo de 15 dias para impugnação por outro recurso, caso caiba, que, passado esse prazo, terá por transitada em julgado a decisão do acórdão a quo.

Nada dispõe o artigo sobre tal aspecto, porém não se deverá considerar tal decisão irrecorrível, pois dessa forma restaria violado o principio constitucional do devido processo legal.

No caso, o recurso mais adequado seria o agravo de instrumento, na forma do art. 544 do CPC, sustentando o desacordo do acórdão recorrido com decisões proferida pelo STJ. Nesse sentido também se posicionam Luiz Rodrigues Wambier e Rita de Cássia Corrêa de Vasconcelos:

"A despeito do silêncio da lei quanto a recorribilidade das decisóes tomadas com base no Art. 543-C, $\$ 7^{\circ}$, parece-nos que, na situação do inciso I, ou seja, negativa de seguimento ao recurso 
que estava suspenso, não poderá ser negada a via recursal permitindo-se a interposição de agravo de instrumento ao STJ (CPC. Art. 544). Até porque, é possível que se esteja diante de hipótese em que não haja identidade ente a questão veiculada no recurso sobrestado e a que se julgou no recurso escolhido." (Wambier e Vasconcelos 2008, P. 31)

$\mathrm{Na}$ hipótese do inciso II, do $\S 7^{\circ}$ do Art. 543-C, que dispõe que serão novamente examinados pelo Tribunal de origem quando o acórdão recorrido divergir da orientação do STJ, sustenta o já invocado Daniel Moura Nogueira que:

\begin{abstract}
"Por outro lado, se o acórdão do recurso especial representante da classe dos recursos análogos tiver posição contrária ao acórdão a quo, o Tribunal de segunda instância deverá proceder um novo exame ao recurso especial e, mesmo silente o Art. 543-C, outra conclusão não há senão que este exame seja dos requisitos de cabimento na esfera excepcional, podendo, caso entenda presente, fazer subir ao STJ o recurso que se encontrava sobrestado, como dispõe o Art. $7^{o}$, II e $\$ 8^{o}$, do artigo em comento." (Nogueira 2008, P. 241)
\end{abstract}

Com isso, divergindo o acórdão recorrido da orientação do Superior Tribunal de Justiça, deverá o recurso ser novamente examinado pelo Tribunal de origem. Mantida a decisão divergente pelo Tribunal de origem, será feito o exame de admissibilidade do recurso especial, conforme dispõe o $\S 8^{\circ}$, do art. 543-C, do CPC.

Luiz Rodrigues Wambier e Rita de Cássia Corrêa de Vasconcelos acreditam que esse dispositivo prevê um juízo de retratação, uma vez que se permite, ao Tribunal local, rever sua posição diante da orientação consolidada no STJ ${ }^{19}$. (Wambier e Vasconcelos 2008, P. 32)

19 "IMPOSTO DE RENDA SOBRE COMPLEMENTAÇÃO DE APOSENTADORIA. LEI N $N^{o}$ 7.713/88. LEI No 9.250/95. BITRIBUTAÇÃO. SUPERIOR TRIBUNAL DE JUSTIÇA. RECURSO REPETITIVO. PRESCRIÇÃO.

1. Quanto à interpretação do art. 168 do CTN, havia sido consolidada, no Superior Tribunal de Justiça, a tese dos "cinco mais cinco", contando-se o prazo prescricional apenas a partir da homologação tácita do pagamento indevido. Já grande parte da doutrina e algumas 
jurisprudências contrárias entendiam que a contagem deveria ser feita a partir do próprio pagamento indevido, sem a necessidade de haver homologação.

2. A Lei Complementar $n^{o} 118 / 2005$ foi editada com o propósito de sedimentar a discussão, em sentido contrário ao defendido pelo Superior Tribunal de Justiça.

3. O advento da referida lei causou impacto nos contribuintes, mormente com relação às suas expectativas quando do ingresso no Judiciário. Amparados na consolidada jurisprudência do Superior Tribunal de Justiça, os contribuintes formularam demandas que, em muitos casos, seriam desacolhidas pela ocorrência de prescrição, caso não adotada a referida orientação jurisprudencial. Foi trazida situação, pois, que não se compadece com os princípios da segurança jurídica e da isonomia, já que possibilitou a desigualdade de tratamento entre os contribuintes tomando por base, exclusivamente, a data de prolação da decisão.

4. Atento a esse reflexo nas ações ajuizadas, o Superior Tribunal de Justiça veio a consolidar entendimento no sentido de que, malgrado o disposto no art. $4^{\circ}$ da Lei Complementar $n^{\circ} 118 / 2005$, sua aplicação não pode ser imediata, pois houve inovação no ordenamento jurídico.

5. Com efeito, fica firmada a premissa de que a lei complementar em comento efetivamente causou situação de instabilidade em relação aos contribuintes.

6. Adoto, pois, o posicionamento do Superior Tribunal de Justiça, nesse contexto, fazendo uma interpretação conforme da norma do art. 4 o da LC $n^{\circ}$ 118/2005, para deixar de aplicá-la retroativamente aos casos em que os contribuintes já haviam ajuizado ações até a data de sua vigência.O recebimento da complementação de aposentadoria decorre de vínculo contratual existente entre o participante e a entidade de previdência privada. Não se trata de devolução de valores, de modo que não existe correspondência entre aquilo que foi recolhido pelo beneficiário e que será recebido na aposentadoria.

7. A questão dos autos refere-se ao período de transição entre duas leis, ou seja, envolve pessoas que contribuíram determinado período sob a égide da Lei $n^{\circ} 7.713 / 88$, sofrendo desconto de imposto de renda em suas contribuições, e continuaram contribuindo por algum tempo ainda após o advento da Lei $n^{\circ} 9.250 / 95$, e sob sua sistemática vieram a se aposentar. Nesse caso, tendo em vista que essa última lei determina a incidência do imposto de renda sobre os valores recebidos como complementação de aposentadoria, alega-se a ocorrência de bis in idem, porque, no tocante às contribuições que foram pagas sob a vigência da legislação anterior, o imposto estaria incidindo tanto sobre as contribuições quanto sobre os benefícios pagos.

8. Inicialmente, em grande parte dos precedentes por mim proferidos, adotei posição, respaldado em precedente da Eminente Ministra Eliana Calmon, no sentido da improcedência do pedido autoral, mediante a distinção entre os valores que são recebidos a título de complementação de aposentadoria e aqueles que são recebidos a título de resgate do montante correspondente às contribuições para a previdência privada. 9. Não obstante, o Superior Tribunal de Justiça, por ocasião do julgamento do REsp 1012903 (DJE 13/10/2008), pacificou a questão em sentido contrário. Tal recurso foi julgado já sob o regime do art. 543-C do CPC e da Resolução STJ $n^{o}$ 08/08, que disciplinam o regramento dos recursos repetitivos. 
O tribunal de origem poderá ou não retratar o acórdão recorrido, levando em conta a divergência com o posicionamento do STJ. Se ocorrer a retratação, o Recurso Especial ficará prejudicado pela perda do objeto. Se for mantido o acórdão pelo colegiado do Tribunal local, o Recurso Especial será admitido.

\subsection{6 - DA NECESSIDADE DE REGULAMENTAÇÃO}

O $\S 9^{\circ}$, do Art. 543-C, do CPC, dispõe que o Superior Tribunal de Justiça e os Tribunais de segunda instância regulamentarão, no âmbito de suas competências, os procedimentos relativos ao processamento e julgamento do recurso especial nos casos previstos neste artigo.

O Art. 96, I, a, da Constituição da República ${ }^{20}$ e o Art. 21, III, da Lei Orgânica da Magistratura Nacional (Lei Complementar 35/1979) $)^{21}$, fundamentam o poder de regulamentar do Superior Tribunal de Justiça.

10. Em consagração, pois, às finalidades propostas pela inovação legislativa em comento - que, visa, essencialmente, conferir maior celeridade e racionalidade ao serviço de prestação jurisdicional, garantindo, ainda, a uniformidade nas decisões judiciais sobre assuntos idênticos -, altero meu posicionamento para acompanhar o entendimento daquela Colenda Corte.

11. Apelação provida." ( TRF, SEGUNDA REGIÃO, APELAÇÃO CÍVEL $n^{o}$. 385889, Processo 200351010258760 - RJ, QUARTA TURMA ESPECIALIZADA, Data da decisão: 25/11/2008) (Grifou-se)

20 “Art. 96. Compete privativamente:

I - aos Tribunais:

a) eleger seus órgãos diretivos e elaborar seus regimentos internos, com observância das normas de processo e das garantias processuais das partes, dispondo sobre a competência e o funcionamento dos respectivos órgãos jurisdicionais e administrativos;"

21 “Art. 21 - Compete aos Tribunais, privativamente:

(...)

III - elaborar seus regimentos internos e neles estabelecer, observada esta Lei, a competência de suas Câmaras ou Turmas isoladas, Grupos, Seções ou outros órgãos com funções jurisdicionais ou administrativas." 
Com fundamento no Art. 21, XX, do Regimento Interno do Superior Tribunal de Justiça ${ }^{22}$, foi editada a Resolução ${ }^{\circ}$. $7 / 2008$.

Esta, todavia, teve curta vigência, tendo sido revogada em 07.08.2008, pela Resolução $n^{\circ}$ 8/2008 (mediante disposição do seu artigo $8^{\circ}$ ), do mesmo Tribunal Superior, que passou a vigorar em 08.08.2008. (Serau Júnior e Reis 2009, P. 65)

A Resolução $n^{\circ}$. 8/2008 atualmente regulamenta todo o trâmite, processamento e julgamento dos recursos especiais repetitivos no STJ.

Nesse sentido o Tribunal de Justiça do Estado do Rio de Janeiro editou a Resolução nº 3/2009 para regulamentar o trâmite dos referidos recursos no âmbito de seu Tribunal.

\subsection{7 - DA VIGÊNCIA DA LEI 11.672/08}

O Art. $2^{\circ}$, da Lei 11.672/2008, que adiciona ao CPC o Art. 543-C, dispõe que a referida lei se aplica aos recursos já interpostos por ocasião da sua entrada em vigor.

A Lei de Introdução ao Código Civil, em seu Art. $1^{\circ}$, dispõe que salvo disposição contrária, a lei começa a vigorar em todo o país quarenta e cinco dias depois de oficialmente publicada.

O Art. $3^{\circ}$, da Lei $11.672 / 2008$, por sua vez, dispõe que a lei entra em vigor 90 (noventa) dias após a data de sua publicação.

\footnotetext{
22 “Art. 21. São atribuições do Presidente: (...) $X X$ - baixar as resoluções e instruções normativas referentes à deliberação do Plenário, da Corte Especial ou do Conselho de Administração, bem como as que digam respeito à rotina dos trabalhos de distribuição;"
} 
Nesse sentido, explicam Marco Aurélio Serau Júnior e Silas Mendes de Carvalho que considerando que a publicação da lei, editada em 08.05.2008, ocorreu em 09.05.2008, esse prazo estabelecido de noventa dias escoou-se em 08.08.2008, a partir de quando adquiriu plena eficácia a nova sistemática processual do Recurso Especial (Serau Júnior e Reis 2009).(Serau Júnior e Reis 2009, P. 65)

O que podemos compreender no caso é que de acordo com a disposição expressa no Art. $2^{\circ}$, da Lei 11.672/08, os recursos especiais interpostos anteriormente a sua vigência não sofreram prejuízo em sua regularidade formal (Serau Júnior e Reis 2009. P. 67).

Nesse sentido, afirma Moacyr Amaral Santos, citado pelos acima referidos autores, que:

\footnotetext{
"A lei nova atinge o processo em curso no ponto em que este se achar, no momento em que ela entrar em vigor, sendo resguardada a inteira eficácia dos atos processuais até então praticados. São os atos posteriores à lei nova que se regularão conforme os preceitos desta." (Amaral Santos, Moacyr. Primeiras Linhas de Direito Processual Civil. 7. Ed. Atual. São Paulo: saraiva, 1980. V. 1. apud Serau Júnior e Reis 2009, P. 66)
}

Porém, serão processados de acordo com a nova sistemática processual, quer dizer: havendo multiplicidade de demandas com idêntica questão de direito, estarão autorizados os Tribunais (Superior Tribunal de Justiça, Tribunal Regional Federal, Tribunais de Justiça dos Estados e o Tribunal de Justiça do Distrito Federal, no exercício de suas respectivas atribuições) a processá-los nos moldes do Art. 543-C, do CPC (Serau Júnior e Reis 2009, P. 67).

Essa deve ser a interpretação do referido artigo. Presentes os pressupostos para a aplicação do procedimento previsto no Art. 543-C, do CPC, aplicar-se-á aos recursos já interpostos por 
ocasião da sua entrada em vigor o procedimento de julgamento dos recursos repetitivos, sendo resguardada a inteira eficácia dos atos processuais até então praticados.

\subsection{8 - DO EFEITO SUSPENSIVO DO RECURSO ESPECIAL REPETITIVO E A INVIABILIDADE DE EXECUÇÃO PROVISÓRIA}

O Art. 497, do CPC, dispõe que "o recurso extraordinário e o recurso especial não impedem a execução da sentença; a interposição do agravo de instrumento não obsta o andamento do processo, ressalvado o disposto no Art. 558 desta Lei."

Além disso, dispõe o Art. 27, §2ª da Lei 8.038/1990, que institui normas procedimentais para os processos que tramitam perante o Superior Tribunal de Justiça e o Supremo Tribunal Federal, e o Art. 542, $\$ 2^{\circ}$ do CPC, que os recursos extraordinário e especial serão recebidos no efeito devolutivo.

Sendo recebido apenas no seu efeito devolutivo, caberia em tese a execução provisória, nos termos dos arts. 497 e 475-I, $\S 1^{\mathrm{o} 23}$, do CPC.

Porém, com a nova lei de recursos repetitivos, os recursos especiais enquadrados nesse caso ficariam suspensos por determinação do Art. 543-C, do CPC, impossibilitando dessa forma a execução provisória.

O Art. 266 do $\mathrm{CPC}^{24}$ dispõe que durante a suspensão é defeso praticar qualquer ato processual, podendo o juiz,

\footnotetext{
23 “Art. 475-I. O cumprimento da sentença far-se-á conforme os arts. 461 e 461-A desta Lei ou, tratando-se de obrigação por quantia certa, por execução, nos termos dos demais artigos deste Capítulo.

$\S 1 o$ É definitiva a execução da sentença transitada em julgado e provisória quando se tratar de sentença impugnada mediante recurso ao qual não foi atribuído efeito suspensivo.

\$ 2 o Quando na sentença houver uma parte líquida e outra ilíquida, ao credor é lícito promover simultaneamente a execução daquela e, em autos apartados, a liquidação desta."
} 
todavia, determinar a realização de atos urgentes, a fim de evitar dano irreparável.

A mais esclarecedora posição com relação aos efeitos que esses recursos teriam é a exposta por Daniel Moura Nogueira, que diz que os recursos teriam um efeito suspensivo oblíquo:

\begin{abstract}
"Sendo o Recurso Especial recebido, como regra, apenas no efeito devolutivo e fazendo parte do grupo dos recursos repetitivos análogos, na forma do novo comando do Art. 543-C do CPC, terá uma nova sistemática por via oblíqua, na qual o que não era suspenso passará a ser, pois, terá suspensos os efeitos por interpretação sistemática do artigo em comento, com os arts. $265^{25}$ e 266, do mesmo Código, ou seja, nem um ato se praticará.
\end{abstract}

24 “Art. 266. Durante a suspensão é defeso praticar qualquer ato processual; poderá o juiz, todavia, determinar a realização de atos urgentes, a fim de evitar dano irreparável."

25 “Art. 265. Suspende-se o processo:

I - pela morte ou perda da capacidade processual de qualquer das partes, de seu representante legal ou de seu procurador;

II - pela convenção das partes;

III - quando for oposta exceção de incompetência do juízo, da câmara ou do Tribunal, bem como de suspeição ou impedimento do juiz;

IV - quando a sentença de mérito:

a) depender do julgamento de outra causa, ou da declaração da existência ou inexistência da relação jurídica, que constitua o objeto principal de outro processo pendente;

b) não puder ser proferida senão depois de verificado determinado fato, ou de produzida certa prova, requisitada a outro juízo;

c) tiver por pressuposto o julgamento de questão de estado, requerido como declaração incidente;

$V$ - por motivo de força maior;

VI - nos demais casos, que este Código regula.

$\S 1$ o No caso de morte ou perda da capacidade processual de qualquer das partes, ou de seu representante legal, provado o falecimento ou a incapacidade, o juiz suspenderá o processo, salvo se já tiver iniciado a audiência de instrução e julgamento; caso em que:

a) o advogado continuará no processo até o encerramento da audiência;

b) o processo só se suspenderá a partir da publicação da sentença ou do acórdão.

$\S 2$ o No caso de morte do procurador de qualquer das partes, ainda que iniciada a audiência de instrução e julgamento, o juiz marcará, a fim de que a parte constitua novo mandatário, o prazo de 20 (vinte) dias, findo o qual extinguirá o processo sem julgamento do mérito, se o autor não nomear novo mandatário, ou mandará prosseguir no processo, à revelia do réu, tendo falecido o advogado deste.

$\S 3$ o A suspensão do processo por convenção das partes, de que trata o no $\mathrm{Il}$, nunca poderá exceder 6 (seis) meses; findo o prazo, o escrivão 
Por essa razão, ainda, nem mesmo execução provisória será realizada, pois, a norma é clara e taxatixa, nenhum ato será praticado." (Nogueira 2008, P. 242)

Dessa forma, o recurso especial que não tinha efeito suspensivo, por determinação da nova regra do Art. 543-C, passará a ter, no caso dos recursos especiais repetitivos, sem haver a possibilidade de ser praticado nenhum ato, inviabilizando a possibilidade de execução provisória.

\subsection{9 - DO RECURSO CONTRA DECISÃO QUE SUSPENDE O RECURSO ESPECIAL}

O Art. 543-C, $\S 1^{\circ}$, do CPC, dispõe que quando o Presidente do Tribunal de origem admitir um ou mais recursos representativos da controvérsia, que serão encaminhados ao STJ, ficarão suspensos os demais recursos especiais até o pronunciamento definitivo do Superior Tribunal de Justiça.

Uma das questões mais importantes que foram discutidas, nesse caso, diz a respeito à possibilidade de da insurgência contra a decisão que determina essa suspensão do recurso. Marco Aurélio Serau Júnior e Silas Mendes dos Reis apresentam em sua obra quatro possibilidades:

A primeira seria o caso de formular pedido de reconsideração, perante o órgão prolator da decisão, aduzindose a ausência de identidade com que a questão de direito versada no recurso tido como representativo. (Carneiro, Athos Gusmão. Primeiras Observações sobre a lei dos recursos

fará os autos conclusos ao juiz, que ordenará o prosseguimento do processo.

$\S 40$ No caso do no III, a exceção, em primeiro grau da jurisdição, será processada na forma do disposto neste Livro, Título VIII, Capítulo II, Seção III; e, no Tribunal, consoante Ihe estabelecer o regimento interno. $\S 5$ o Nos casos enumerados nas letras $a, b$ e c do no $I V$, o período de suspensão nunca poderá exceder 1 (um) ano. Findo este prazo, o juiz mandará prosseguir no processo." 
repetitivos no STJ. Revista de Processo, São Paulo: RT, ano 33, n. 160, jun.2008 apud Serau Júnior e Reis 2009, P. 75)

Poderiam ser opostos embargos de declaração, com fulcro no Art. 535, $\mathrm{I}^{26}$, do CPC, alegando contradição entre o teor do recurso especial inadequadamente suspenso e a controvérsia versada em recurso representativo.

Outra possibilidade de destrancamento do recurso especial suspenso poderia ser feita com o uso do agravo de instrumento previsto no Art. $544^{27}$, do CPC, direcionado ao próprio Superior Tribunal de Justiça.

Além disso, os autores supra citados admitem, outrossim, a possibilidade de apresentação de reclamação perante o próprio STJ, com fundamento no Art. 105, I, “f”, da Constituição Federal $^{28}$, a fim de restar preservada a competência do mesmo.

No caso, a mais adequada posição a ser adotada seria a oposição de embargos de declaração, para se alegar contradição entre o teor do recurso especial inadequadamente suspenso e a controvérsia versada em recurso representativo.

Não seria apropriado, visando a finalidade da lei, que se permitissem diversos recursos para o STJ em face dessa suspensão, pois a quantidade de demandas aumentaria novamente no âmbito do referido tribunal superior, tornando

\footnotetext{
${ }^{26}$ Art. 535. Cabem embargos de declaração quando:

I - houver, na sentença ou no acórdão, obscuridade ou contradição.

${ }^{27}$ Art. 544. Não admitido o recurso extraordinário ou o recurso especial, caberá agravo de instrumento, no prazo de 10 (dez) dias, para o Supremo Tribunal Federal ou para o Superior Tribunal de Justiça, conforme o caso.

28 “Art. 105. Compete ao Superior Tribunal de Justiça:

I - processar e julgar, originariamente:

(...)

f) a reclamação para a preservação de sua competência e garantia da autoridade de suas decisões."
} 
sem sentido toda reforma processual inserida pelo Art. 543-C, que tem o intenção de diminuir a quantidade de processos no STJ e proporcionar julgamentos mais céleres, devendo dessa forma serem evitados o recurso de agravo de instrumento. Além disso, com relação ao agravo de instrumento, a Resolução $n^{\circ} .8$ em seu art. $7^{\circ}$, diz que se aplica ao agravo de instrumento o procedimento dos recursos repetitivos no que couber.

Também não seria adequado o uso da Reclamação perante o STJ, pois a mesma consiste no meio através do qual se leva as cortes superiores a notícia da usurpação de sua competência ou desobediência a julgado seu, cometida por juiz ou tribunal inferior, que não é o caso.

Se a idêntica questão de direito for verificada em recurso especial que já está sobre a apreciação do STJ, com base no Art. $259^{29}$, do RISTJ os ministros têm usado o juízo de retratação. Ocorrendo até mesmo a retratação de decisões monocráticas já proferidas julgado o recurso interposto, para torná-las sem efeito, sobrestando o recurso que foi identificado como repetitivo até o julgamento final do processo representativo da controvérsia pelo órgão competente do $\mathrm{STJ}^{30}$.

\footnotetext{
29 “Art. 259. O agravo regimental será submetido ao prolator da decisão, que poderá reconsiderá-la ou submeter o agravo ao julgamento da Corte Especial, da Seção ou da Turma, conforme o caso, computando-se também o seu voto."

30 "PROCESSUAL CIVIL E ADMINISTRATIVO - PRECATÓRIO HONORÁRIOS DE SUCUMBÊNCIA - DIREITO AUTONNOMO DO ADVOGADO - CESSÃO DE CRÉDITO - PEDIDO DE RECONSIDERAÇÃO - PROCESSO SUBMETIDO AO REGIME DE RECURSO REPETITIVO (RESP 1.102.473/RS) - IMPOSSIBILIDADE DE JULGAMENTO DO RECURSO - JUÍZO DE RETRATAÇÃO PARA TORNAR SEM EFEITO A DECISÃO AGRAVADA E SOBRESTAR O RECURSO ATÉ O JULGAMENTO DO CASO REPRESENTATIVO DA CONTROVÉRSIA.

DECISÃO Vistos.

(...)

De fato, a matéria objeto do recurso especial insere-se nos moldes de processo afeto à Corte Especial do Superior Tribunal de Justiça,
} 
especificamente o REsp 1.102.473/RS, para os fins do que dispõe o art. 543-C do CPC.

Nessa circunstância, o presente recurso tem natureza repetitiva, porquanto há multiplicidade de espécies recursais, com fundamento em idêntica questão de direito. Dessa forma, o presente recurso especial não poderia ter sido julgado monocraticamente antes do julgamento do citado paradigma, em obediência ao $\S 1^{\circ}$ do art. 543-C do CPC, incluído pela Lei n. 11.672/2008, verbis: "Caberá ao presidente do tribunal de origem admitir um ou mais recursos representativos da controvérsia, os quais serão encaminhados ao Superior Tribunal de Justiça, ficando suspensos os demais recursos especiais até o pronunciamento definitivo do Superior Tribunal de Justiça." No mesmo sentido dispõe o art. $2^{\circ}$, $\S$ $2^{\circ}$, da Resolução n. 8/2008, in litteris: "A decisão do Relator será comunicada aos demais Ministros e ao Presidente dos Tribunais de Justiça e dos Tribunais Regionais Federais, conforme o caso, para suspender os recursos que versem sobre a mesma controvérsia." Assim, utilizando-me do juízo de retratação, com fundamento no art. 557, $\$ 1^{\circ}$, do CPC, reconsidero a decisão de fls. 100-104, para tornar sem efeito o referido decisum e determinar o sobrestamento deste recurso até o julgamento final do processo representativo da controvérsia pelo órgão competente do Superior Tribunal de Justiça. Publique-se. Intimemse."(AgRg no RECURSO ESPECIAL N $N^{o} 1.100 .286$ - RS (2008/0232432-5) RELATOR : MINISTRO HUMBERTO MARTINS) 


\section{4 - RESOLUÇÕES DO SUPERIOR TRIBUNAL DE JUSTIÇA E DO TRIBUNAL DE JUSTIÇA DO ESTADO DO RIO DE JANEIRO}

\section{1 - RESOLUÇÃO №. 7/2008 DO SUPERIOR TRIBUNAL DE JUSTIÇA}

Em 17.07.2008, foi publicada, no Diário de Justiça eletrônico da União, a Resolução $n^{\circ}$ 7/2008 do STJ, que estabelecia os procedimentos relativos ao processamento e julgamento de recursos especiais repetitivos.

A referida Resolução foi editada pelo Presidente do Superior Tribunal de Justiça, no uso das atribuições conferidas pelo Art. 21, XX, do Regimento Interno do Superior Tribunal de Justiçaa ${ }^{31}$, considerando a necessidade de regulamentar os procedimentos para admissibilidade e julgamento dos recursos especiais repetitivos, previstos na Lei $n^{\circ} .11 .672$, de 8 de maio de 2008, em relação ao Superior Tribunal de Justiça e aos Tribunais Regionais Federais e Tribunais de Justiça.

A Resolução $n^{\circ}$. 7/2008 foi criticada por diversas vozes, como pode ser visto no artigo do Desembargador do Tribunal de Justiça do Rio Grande do Sul, Carlos Alberto Etcheverry:

\footnotetext{
"O regulamento em questão, entretanto, fez mais do que disciplinar o processamento e julgamento dos recursos repetitivos no STJ, pois invadiu a esfera de competência dos Tribunais de segunda instância e do Poder Legislativo, uma vez que:
}

\footnotetext{
31 “Art. 21. São atribuições do Presidente: (...)

$X X$ - baixar as resoluções e instruções normativas referentes à deliberação do Plenário, da Corte Especial ou do Conselho de Administração, bem como as que digam respeito à rotina dos trabalhos de distribuição;"
} 
a) atribui ao Presidente dos Tribunais de segunda instância a faculdade de suspender o andamento de recursos ainda náo julgados e de processos no primeiro grau de jurisdição (Art. $1^{o}$, $\S \S 3^{\circ}$ e $\left.4^{\circ}\right)$, o que a lei não prevê;

b) determina que os órgãos fracionários reconsiderem suas decisões, se contrariarem a posição firmada pelo STJ, o que contraria disposição expressa da lei regulamentada, que faculta a manutenção do julgado (Art. 10, II);

c) determina que os "processos suspensos em primeiro grau de jurisdição serão decididos de acordo com a orientação firmada pelo Superior Tribunal de Justiça" (Art. 12), o que também não é previsto na lei regulamentada.

Ou seja, com uma penada o Ministro Humberto Gomes de Barros contrariou de forma flagrante:

a) o Art. 96, I, "a" da Constituição Federal, que atribui aos Tribunais, privativamente, a competência para elaborar seus regimentos internos e dispor sobre a competência e funcionamento de seus órgãos jurisdicionais;

b) o Art. 44 da Constituição Federal, pois usurpou função legislar - que é privativa do Poder Legislativo;

c) o princípio constitucional da independência do juiz, que deflui da regulamentação constitucional da separação dos poderes e das garantias asseguradas à magistratura, cuja única exceção é a da súmula vinculante do Supremo Tribunal Federal.

A Resolução $n^{\circ} 7 / 2008$, assim, caracteriza-se como o mais violento atentado ao Estado Democrático de Direito desde a Revolução de 1964. E o mais chocante também, considerando-se que foi praticado pelo Presidente de um Tribunal superior e não por um general qualquer durante um regime de exceção. (Etcheverry 2008)"

Tendo em vista estas severas críticas, no dia 07/08/08, finalmente, o novo Presidente do STJ, ministro Cesar Asfor Rocha, remendou a situação editando a Resolução n ${ }^{\circ}$ 8/2008, que revogou a anterior e ofereceu nova orientação ao processamento dos recursos especiais repetitivos, às vésperas do início de vigência do novel Art. 543-C do CPC. (Pomar 2008)

Com isso, a Resolução n ${ }^{\circ}$ 7/2008, de 14 de julho de 2008, foi revogada pelo Art. $8^{\circ}$ da Resolução $n^{\circ}$. 8, que entrou em vigor em 8 de agosto de 2008.

\section{2 - RESOLUÇÃO №. 8/2008 DO SUPERIOR TRIBUNAL DE JUSTIÇA}


A Resolução $n^{\circ}$. 8/2008, que atualmente regulamenta o trâmite dos recursos especiais repetitivos, foi elaborada, considerando a necessidade de regulamentar os procedimentos para admissibilidade e julgamento dos recursos especiais repetitivos, previstos na Lei $n^{\circ} .11 .672$, de 8 de maio de 2008.

Serão analisadas, nesse ponto, as inovações que a Resolução $n^{\circ} .8$ do STJ traz.

No mesmo sentido da lei, dispõe o Art. $1^{\circ}$ da Resolução em foco, que havendo multiplicidade de recursos especiais com fundamento em idêntica questão de direito, caberá ao Presidente ou ao Vice-Presidente do Tribunal recorrido (CPC, Art. 541) admitir um ou mais recursos representativos da controvérsia, os quais serão encaminhados ao Superior Tribunal de Justiça, ficando os demais suspensos até o pronunciamento definitivo do Tribunal.

Serão selecionados pelo menos um processo de cada Relator e, dentre esses, os que contiverem maior diversidade de fundamentos no acórdão e de argumentos no recurso especial (Art. $\left.1^{\circ}, \S 1^{\circ}\right)$. O agrupamento de recursos repetitivos levará em consideração apenas a questão central discutida, sempre que o exame desta possa tornar prejudicada a análise de outras questões argüidas no mesmo recurso (Art. $2^{\circ}, \S 2^{\circ}$ ).

$\mathrm{O} \S 3^{\circ}$ do Art. $1^{\circ}$ da referida Resolução determina que a suspensão, de que trata o caput do Art. $1^{\circ}$ da mesma e o $\S 1^{\circ}$ do Art. 543-C, do CPC, será certificada nos autos. Já o $§ 4^{\circ}$ dispõe que no STJ, os recursos especiais de que trata este artigo serão distribuídos por dependência e submetidos a julgamento nos termos do Art. 543-C do CPC e desta Resolução.

O Art. $2^{\circ}$ dispõe que recebendo recurso especial admitido com base no artigo $1^{\circ}$, caput, da Resolução, o Relator submeterá o seu julgamento à Seção ou à Corte Especial, desde 
que, nesta última hipótese, exista questão de competência de mais de uma Seção. A critério do Relator, poderão ser submetidos ao julgamento da Seção ou da Corte Especial, na forma do aludido artigo, recursos especiais já distribuídos que forem representativos de questão jurídica objeto de recursos repetitivos. (Art. $\left.2^{\circ}, \S 1^{\circ}\right)$ A decisão do Relator será comunicada aos demais Ministros e ao Presidente dos Tribunais de Justiça e dos Tribunais Regionais Federais, conforme o caso, para que suspendam os recursos que versem sobre a mesma controvérsia. (Art. $\left.2^{\circ}, \S 2^{\circ}\right)$

Determina o Art. $3^{\circ}$ que, antes do julgamento do recurso, o Relator poderá solicitar informações aos Tribunais Estaduais, ao Tribunal do Distrito Federal ou aos Tribunais Federais a respeito da controvérsia e autorizar, ante a relevância da matéria, a manifestação escrita de pessoas, órgãos ou entidades com interesse na controvérsia, a serem prestadas no prazo de quinze dias ou poderá dar vista dos autos ao Ministério Público por quinze dias.

$\mathrm{Na}$ Seção ou na Corte Especial, o recurso especial será julgado com preferência sobre os demais, ressalvados os que envolvam réu preso e os pedidos de habeas corpus (Art. $4^{\circ}$ ). O parágrafo único do Art. $4^{\circ}$ estabelece que a Coordenadoria do órgão julgador extrairá cópias do acórdão recorrido, do recurso especial, das contra-razões, da decisão de admissibilidade, do parecer do Ministério Público e de outras peças indicadas pelo Relator, encaminhando-as aos integrantes do órgão julgador pelo menos 5 (cinco) dias antes do julgamento.

$\mathrm{O}$ artigo $5^{\circ}$ dispõe sobre o procedimento a ser seguido a partir da publicação do acórdão do julgamento do recurso paradigma. Os recursos fundados em idêntica controvérsia de direito (I) se já tiverem sido distribuídos para um Ministro 
Relator no âmbito do STJ, deverão ser julgados de forma monocrática por este nos moldes do Art. 557, do $\mathrm{CPC}^{32}$; (II) se já estiverem no STJ, mas se ainda não tiverem sido distribuídos, serão julgados pela Presidência, nos termos da Resolução $\mathrm{n}^{\mathrm{o}}$. 3 de abril de $2008^{33}$; ou (III) se os recursos estiverem sobrestados na origem, deverão seguir a forma do $\S \S$ $7^{\circ}$ e $8^{\circ}$ do Art. 543-C, do CPC, ou seja, I - terão seguimento denegado na hipótese de o acórdão recorrido coincidir com a orientação do Superior Tribunal de Justiça; ou II - serão novamente examinados pelo Tribunal de origem na hipótese de o acórdão recorrido divergir da orientação do Superior Tribunal de Justiça, na hipótese prevista no inciso II do $\S 7^{\circ}$, do Art. 543-C, do CPC,. Caso seja mantida a decisão divergente pelo

32 Art. 557. O relator negará seguimento a recurso manifestamente inadmissível, improcedente, prejudicado ou em confronto com súmula ou com jurisprudência dominante do respectivo Tribunal, do Supremo Tribunal Federal, ou de Tribunal Superior.

$\S 10-A$ Se a decisão recorrida estiver em manifesto confronto com súmula ou com jurisprudência dominante do Supremo Tribunal Federal, ou de Tribunal Superior, o relator poderá dar provimento ao recurso.

$\S 1$ o Da decisão caberá agravo, no prazo de cinco dias, ao órgão competente para o julgamento do recurso, e, se não houver retratação, o relator apresentará o processo em mesa, proferindo voto; provido o agravo, o recurso terá seguimento.

\$ 2 o Quando manifestamente inadmissível ou infundado o agravo, o Tribunal condenará o agravante a pagar ao agravado multa entre um e dez por cento do valor corrigido da causa, ficando a interposição de qualquer outro recurso condicionada ao depósito do respectivo valor.

33 Art. $1^{\circ}$ Compete ao Presidente, antes da distribuição:

I - não conhecer de agravo de instrumento manifestamente inadmissível;

II - negar seguimento a recurso especial manifestamente inadmissível, prejudicado ou em confronto com súmula ou jurisprudência dominante no Tribunal;

III - dar provimento a recurso especial, se o acórdão recorrido estiver em confronto com súmula ou jurisprudência dominante no Tribunal;

IV - conhecer de agravo de instrumento para:

a) negar seguimento a recurso especial, na hipótese prevista no inciso II;

b) dar provimento a recurso especial, na hipótese prevista no inciso III.

$\S 1^{\circ} O$ Presidente julgará embargos de declaração opostos contra as decisões que emitir.

$\S 2^{\circ}$ Interposto agravo regimental contra decisão emitida pelo Presidente, os autos serão distribuídos, observando-se o Art. $9^{o}$ do Regimento Interno. 
Tribunal de origem, far-se-á o exame de admissibilidade do recurso especial.

Dispõe o Art. $6^{\circ}$, da Resolução $\mathrm{n}^{\circ} 8$, que a coordenadoria do órgão julgador expedirá ofício aos Tribunais de origem com cópia do acórdão relativo ao recurso especial julgado.

Inovou a Resolução $\mathrm{n}^{\circ}$. 8, em seu Art. $6^{\circ}$, ao dispor que o procedimento nela estabelecido Resoluçãoaplica-se, no que couber, aos agravos de instrumento interpostos contra decisão que não admitir recurso especial.

Nesse ponto, Marco Aurélio Serau Júnior e Silas Mendes dos Reis entendem que a não deverão os Tribunais de origem, a fim de não ensejar a interposição de agravo de instrumento, continuar a realizar o exame de admissibilidade prévia desse segmento de recursos especiais (Serau Júnior e Reis 2009, P. $68)$.

Os referidos autores justificam seu posicionamento com dois argumentos:

\begin{abstract}
"O primeiro deles, de ordem eminentemente processual, diz respeito à aplicação isonômica do novo regime processual a todos os feitos que tratem de semelhante matéria. E isso implica a suspensão tanto do recurso especial quanto do eventual agravo de instrumento interposto contra decisão de não-admissão.

$O$ outro argumento, de ordem constitucional, diz respeito às elevadas funções e ao papel das Cortes Superiores, em particular do Superior Tribunal de Justiça, aqui atinentes à uniformização da interpretação da legislação federal comum." (Serau Júnior e Reis 2009, P. 68)
\end{abstract}

O Art. 328- $\mathrm{A}^{34}$, do Regimento Interno do STF, estabeleceu dessa forma com relação aos agravos de instrumento nos casos

\footnotetext{
34 "Art. 328-A. Nos casos previstos no Art. 543-B, caput, do CPC, o Tribunal de origem não emitirá juízo de admissibilidade sobre os recursos extraordinários já sobrestados, nem sobre os que venham a ser interpostos, até que o Supremo Tribunal Federal decida os que tenham sido selecionados nos termos do $\$ 1^{o}$ daquele artigo."
} 
de sobrestamento decorrente da sistemática da repercussão geral, dispondo que nos casos previstos no Art. 543-B ${ }^{35}$, caput, do CPC, o Tribunal de origem não emitirá juízo de admissibilidade sobre os recursos extraordinários já sobrestados, nem sobre os que venham a ser interpostos, até que o STF decida os que tenham sido selecionados nos termos do $\S$ $1^{\circ}$ daquele artigo.

O juízo de admissibilidade, que irá verificar os pressupostos processuais para a interposição do recurso especial, poderá ser feito após o julgamento do recurso paradigma sem prejuízo para as partes. A diferença aqui é que ele será feito em um momento posterior e além disso, caso seja provido o referido recurso no STJ, poderá o referido tribunal, caso deseje converter o agravo de instrumento em recurso especial, desde já aplicar o resultado no julgamento do recurso paradigma ao caso, dando celeridade ao procedimento.

\section{3 - BREVES COMPARATIVOS DE PONTOS POLÊMICOS DAS RESOLUÇÕES}

\subsection{1 - DA SUSPENSÃO DOS PROCESSOS}

As resoluções possuíam posições diferentes com relação a suspensão dos processos sobrestados, como expõem Luiz Rodrigues Wambier e Rita de Cássia Corrêa de Vasconcelos:

\footnotetext{
35 Art. 543-B. Quando houver multiplicidade de recursos com fundamento em idêntica controvérsia, a análise da repercussão geral será processada nos termos do Regimento Interno do Supremo Tribunal Federal, observado o disposto neste artigo.

(...)

$\S 1^{o}$ Caberá ao Presidente do Tribunal de origem admitir um ou mais recursos representativos da controvérsia, os quais serão encaminhados ao Superior Tribunal de Justiça, ficando suspensos os demais recursos especiais até o pronunciamento definitivo do Superior Tribunal de Justiça
} 
"Não é sem propósito mencionar que a Resolução 7, do STJ diferentemente da Resolução 8, que a revogou - estendia a suspensão aos demais recursos e, também aos processos em andamento no primeiro grau de jurisdição. Em seu Art. $1^{\circ}, \$ 3^{\circ}$, da Resolução 7 previa que o Presidente do Tribunal, 'em decisão irrecorrível' (Art. $1^{\circ}, \S 1^{\circ}$, da Resolução 8), poderia estender a suspensão aos demais recursos 'julgados ou não, mesmo antes da distribuição'. E, no $\$ 4^{\circ}$, do mesmo artigo, dispunha que, determinada tal suspensão, esta alcançaria os processos em andamento no primeiro grau de jurisdição que apresentassem igual matéria controvertida independentemente da fase processual em que se encontrassem. Ainda que no $\$ 4^{o}$ não se tenha feito menção expressa à irrecorribilidade da decisão, a referência ao parágrafo anterior levava a crer que se estaria, também aqui, diante de ato irrecorrível.

A Resolução 8, em vigor, felizmente não reproduziu essas regras, que certamente gerariam muita polêmica, em especial no tocante à irrecorribilidade das decisóes. É inequívoco que a suspensão dos demais recursos, alcançando aqueles que sequer foram distribuídos e, também, os processos que tramitam no primeiro grau, poderia causar a parte lesão grave $e$ de difícil reparação.(...)" (Wambier e Vasconcelos 2008, P. 33)

Criticam, assim, a posição tomada pela Resolução $n^{\circ}$. 7/2008, que estendia a suspensão aos demais recursos e aos processos em andamento no primeiro grau de jurisdição. Tendo em vista que essa suspensão poderia causar a parte lesão grave e de difícil reparação.

Os referidos autores afirmam, ainda, que mesmo que houvesse a ampliação dessa suspensão, não poderia o STJ em sede de Resolução, obstar a via recursal. Pois, nesse caso, estar-se-ia diante de outra situação em que, por não se prever mecanismo processual de impugnação, poderia se lançar mão do mandado de segurança, ainda que não seja fácil estabelecer o juízo competente para processá-lo e julgá-lo (Wambier e Vasconcelos 2008, P. 34).

As críticas são pertinentes, visto que, conforme dito anteriormente, o intuito da nova lei foi o de garantir celeridade na tramitação dos recursos em trâmite perante o STJ, porém 
obedecendo sempre ao princípio do devido processo legal, do contraditório e da ampla defesa.

Não poderia o STJ, em sede de resolução que teria o condão de regulamentar o art. 543-C, do CPC, estabelecer uma regra de caráter processual suspendendo o prosseguimento de um processo de $1^{\text {a }}$ instância, ainda em fase cognitiva, que apresentasse questão de direito idêntica a matéria repetitiva que será julgada pelo STJ. Estaríamos aqui diante de uma inconstitucionalidade, visto que apenas a União pode legislar sobre matéria processual (Art. 22, I, da CF) e não poderia o STJ estabelecer em sede de resolução uma regra que impedisse o juiz de primeira instância de colher as provas necessárias para proferir a decisão de mérito dando a parte ou não o bem da vida pleiteado. Em primeira instancia os fatos ainda devem ser analisados, diferente do que ocorreria em sede de recurso especial.

\subsection{2 - EFEITO VINCULANTE DAS DECISÕES EM SEDE DE RECURSOS REPETITIVOS?}

Essa foi uma das grandes críticas à Resolução nº. 7/2008 do STJ. O Art. 12 da referida Resolução dispunha que os processos suspensos em primeiro grau de jurisdição seriam decididos de acordo com a orientação firmada pelo Superior Tribunal de Justiça, incidindo, quando cabível, o disposto nos artigos $285-\mathrm{A}^{36}$ e $518, \S 1^{\mathrm{o} 37}$, do CPC.

\footnotetext{
36 "Art. 285-A. Quando a matéria controvertida for unicamente de direito e no juízo já houver sido proferida sentença de total improcedência em outros casos idênticos, poderá ser dispensada a citação e proferida sentença, reproduzindo-se o teor da anteriormente prolatada.

$\S 1^{o}$ Se o autor apelar, é facultado ao juiz decidir, no prazo de 5 (cinco) dias, não manter a sentença e determinar o prosseguimento da ação. $\S 2^{o}$ Caso seja mantida a sentença, será ordenada a citação do réu para responder ao recurso."
} 
A Resolução $n^{\circ}$. 8 não repetiu essa regra. Nesse sentido comentam Luiz Rodrigues Wambier e Rita de Cássia Corrêa de Vasconcelos:

\begin{abstract}
"Para nós foi acertada a supressão dessa regra na nova regulamentação. A vinculação dos juízes de primeiro grau é ilegítima, pois, a teor da regra constitucional, somente o STF pode editar súmulas vinculantes. Ainda que sem a força da súmula vinculante do STF, seria legítima a disposição revogada se o STJ, logo após o julgamento, editasse súmula da jurisprudência dominante nessa Corte. Somente assim seria justificável - embora não obrigatória - aplicação pelos juízes de primeiro grau das regras mencionadas, em especial a do Art. 518, $\$ 1^{\circ}$, que condiciona o não recebimento do recurso de apelação à circunstância de a sentença apelada estar em conformidade com súmula dos Tribunais Superiores." (Wambier e Vasconcelos 2008, P. 34)
\end{abstract}

Não pode, pois, uma resolução dar efeito vinculante as decisões proferidas em sede de recursos especiais repetitivos, como previa a malsinada Resolução $n^{\circ}$. 7/2008 do STJ, já que somente o STF pode editar súmulas vinculantes de ofício ou por provocação, mediante decisão de dois terços dos seus membros, após reiteradas decisões sobre matéria constitucional ${ }^{38}$.

\title{
4.4 - DA RESOLUÇÃO №. 03/2009 DO TRIBUNAL DE JUSTIÇA DO ESTADO DO RIO DE JANEIRO
}

\footnotetext{
37 “Art. 518. Interposta a apelação, o juiz, declarando os efeitos em que a recebe, mandará dar vista ao apelado para responder $\S 1^{o} O$ juiz não receberá o recurso de apelação quando a sentença estiver em conformidade com súmula do Superior Tribunal de Justiça ou do Supremo Tribunal Federal."

38 “Art. 103-A. O Supremo Tribunal Federal poderá, de ofício ou por provocação, mediante decisão de dois terços dos seus membros, após reiteradas decisões sobre matéria constitucional, aprovar súmula que, a partir de sua publicação na imprensa oficial, terá efeito vinculante em relação aos demais órgãos do Poder Judiciário e à administração pública direta e indireta, nas esferas federal, estadual e municipal, bem como proceder à sua revisão ou cancelamento, na forma estabelecida em lei"
} 
Em 07.05.2009 foi publicada no Diário de Justiça Eletrônico do Estado do Rio de Janeiro - DJERJ, a Resolução $\mathrm{n}^{\circ}$. 3 de 2009 que regula, no âmbito da competência da $3^{\circ}$ VicePresidência do Tribunal de Justiça do Estado do Rio de Janeiro, na forma do Art. 33, II do CODJERJ ${ }^{39}$, o procedimento relativo ao processamento dos recursos extraordinários e especiais com fundamento em idêntica questão de direito, e ainda com apreciação da repercussão geral, nos termos dos arts. 543-B e 543-C do CPC.

Em um mesmo regulamento, o Tribunal de Justiça do Rio de Janeiro dispôs sobre o procedimento a ser adotado, na $3^{\text {a }}$ Vice Presidência, nos recursos especiais repetitivos e nos extraordinários que possuem repercussão geral, sendo que ambos são institutos com características bem diferentes.

A repercussão geral que está prevista na Constituição Federal, em seu Art. $102, \S 3^{\circ}$, da $\mathrm{CF}^{40}$, funciona como um filtro dos recursos extraordinários direcionados ao STF, para concretizar a função do Tribunal Supremo, que é de uniformizar a jurisprudência e não de ser uma mera instância revisora.

A causa a ser julgada deve transcender ao interesse das partes, implicando em um interesse geral, da coletividade.

\footnotetext{
39 Art. 33 - Ao $3^{\circ}$ Vice-Presidente compete:

(...)

II - deferir ou indeferir, por delegação do Presidente do Tribunal e em despacho motivado o seguimento de recursos extraordinários manifestados contra decisões proferidas em última instância pelos órgãos julgadores do Tribunal de Justiça, resolvendo os incidentes que se suscitarem $\left(C P C\right.$, artigo $\left.543, \S 1^{\circ}\right)$;

40 Art. 102. Compete ao Supremo Tribunal Federal, precipuamente, a guarda da Constituição, cabendo-lhe: (...)

$\S 3^{\circ}$ No recurso extraordinário o recorrente deverá demonstrar a repercussão geral das questões constitucionais discutidas no caso, nos termos da lei, a fim de que o Tribunal examine a admissão do recurso, somente podendo recusá-lo pela manifestação de dois terços de seus membros.
} 
Já os recursos repetitivos não se apresentam como modalidade de filtro ou barreira para a interposição de recursos. Consistem em um mecanismo de julgamento em bloco de recursos especiais, voltado, especialmente, para dar celeridade processual aos referidos casos e ao aprimoramento da função especial do Superior Tribunal de Justiça (Serau Júnior e Reis 2009, P. 81).

Por isso, mereciam os referidos institutos serem tratados diferentemente e separados.

Seguem alguns trechos interessantes da referida Resolução:

"O $3^{\circ}$ Vice-Presidente, no uso de suas atribuições legais e à vista das alterações introduzidas pelas Leis 11.418, de 19 de dezembro de 2006, e 11.672, de 08 de maio de 2008,

RESOLVE:

Art. $1^{o}$ - Na hipótese de multiplicidade de recursos extraordinários e especiais com fundamento em idêntica questão de direito, tanto na esfera cível quanto criminal, serão admitidos um ou mais recursos representativos da controvérsia para submissão ao Supremo Tribunal Federal e Superior Tribunal de Justiça, respectivamente.

(...)

Art. $2^{o}-$ Os recursos serão selecionados levando-se em consideração, preferencialmente:

a) a maior diversidade de fundamentos no acórdão e argumentos no recurso especial;

b) a divergência, se existente, entre os órgãos julgadores deste Tribunal, caso em que deverá ser observada a paridade no número de feitos selecionados.

c) a questão central de mérito, sempre que o exame desta puder tornar prejudicada a análise de outras questões periféricas argüidas no mesmo recurso.

d) a inexistência de interposição de outro recurso constitucional simultâneo no mesmo processo, que pudesse retardar o julgamento do paradigma, na forma do Art. 543 e parágrafos do Código de Processo.

Art. $3^{\circ}$ - Os recursos não selecionados ficarão sobrestados até o julgamento do recurso paradigma afetado pelo Tribunal Superior, procedendo-se ao lançamento no sistema de informática.

(...)

Art. $4^{o}$ - Publicado(s) o(s) acórdão(s) do(s) recurso(s) afetado $(s)$ pelo Tribunal Superior, os recursos sobrestados serão desarquivados e encaminhados à conclusão para os fins do Art. 543-B, $\S 2^{\circ}$ e $3^{o}$, e Art. 543-C $\S 7^{\circ}$, do $C P C$.

(...) 
Parágrafo $2^{o}$ - Será certificado nos autos dos processos com recursos sobrestados o julgamento e publicação do acórdão relativo ao recurso paradigma afetado, aplicando-se as seguintes regras:

I - negada a existência de repercussão geral, no caso dos recursos extraordinários, os recursos sobrestados serão automaticamente inadmitidos.

II - coincidindo o acórdão recorrido com o julgamento realizado pelo Supremo Tribunal Federal ou pelo Superior Tribunal de Justiça, declarar-se-á prejudicado o recurso extraordinário interposto e negar-se-á seguimento ao recurso especial interposto;

III - divergindo o acórdão recorrido com o julgamento realizado pelo Supremo Tribunal Federal ou pelo Superior Tribunal de Justiça, serão os autos devolvidos ao órgão julgador competente, com cópia do acórdão do recurso paradigma, para exercício de juízo de retratação, na forma do inciso II do $\$ 7^{o}$ do Art. 543-C do $C P C$ :

a) se mantida a decisão recorrida, em divergência com a orientação do Supremo Tribunal Federal ou do Superior Tribunal de Justiça, sem quaisquer acréscimos ou fundamentos, os autos serão conclusos ao $3^{\circ}$ Vice-Presidente para juízo de admissibilidade do recurso interposto;

b) se reformada a decisão recorrida, adotando a orientação do Supremo Tribunal Federal ou do Superior Tribunal de Justiça, os autos serão conclusos ao $3^{\circ}$ Vice-Presidente, que procederá na forma do inciso $I$.

Art. $5^{\circ}$ - A seleção dos recursos paradigmas e o sobrestamento dos recursos que lhe forem vinculados pressupõe a prévia análise do preenchimento dos requisitos formais $e$ objetivos de admissibilidade recursal; caso contrário, em decisão fundamentada, proceder-se-á diretamente ao juízo de admissibilidade negativo.

(...)

Art. $7^{o}$ - Aplicar-se-á o disposto nesta Resolução aos recursos extraordinários e especiais, pendentes de juízo de admissibilidade, ainda que interpostos antes da vigência dos artigos 543-B e 543-C do CPC, introduzidos pelas Leis 11.418, de 19 de dezembro de 2006, e 11.672, de 08 de maio de 2008, ressalvados os recursos extraordinários interpostos contra acórdãos publicados anteriormente à Emenda Regimental 21/07 do STF, quando negada a existência de repercussão geral.

Art. $8^{\circ}$ - Quanto aos recursos constitucionais que não versem sobre questão controvertida repetitiva, realizar-se-á imediatamente o juízo de admissibilidade." ${ }^{41}$

${ }^{41}$ Íntegra da Resolução pode ser encontrada no site do Tribunal de Justiça do Estado do Rio de Janeiro:

http://www.tj.rj.gov.br/scripts/weblink.mgw?MGWLPN=DIGITAL1A\&P $\mathrm{GM}=\mathrm{WEBBCLE} 66 \& \mathrm{LAB}=\mathrm{BIB} \times \mathrm{WEB} \& \mathrm{AMB}=\mathrm{INTRA} \& \mathrm{TR} \mathrm{IPA}=51 \% 5 \mathrm{E} 200$ $9 \% 5 \mathrm{E} 3 \& \mathrm{PAL}=\& \mathrm{JUR}=\mathrm{EST}$ ADUAL $\& A N O X=2009 \& \mathrm{TIPO}=\mathrm{RESOLUCAOTJ}$ $\mathrm{OE} \& \mathrm{ATO}=3 \& \mathrm{START}=$ 
A Resolução do referido Tribunal de Justiça, no Art. $4^{\circ}, \S$ $2^{\circ}$, estabelece que coincidindo o acórdão recorrido com o julgamento realizado pelo STJ, terá o seguimento negado o recurso especial interposto.

Divergindo o acórdão recorrido com o julgamento realizado pelo STJ, serão os autos devolvidos ao órgão julgador competente, com cópia do acórdão do recurso paradigma, para exercício de juízo de retratação, na forma do inciso II do $\$ 7^{\circ}$ do Art. 543- C, do CPC.

Nesse último caso, se mantida a decisão recorrida, em divergência com a orientação do Superior Tribunal de Justiça, sem quaisquer acréscimos ou fundamentos, os autos serão conclusos ao $3^{\circ}$ Vice-Presidente para juízo de admissibilidade do recurso interposto.

Caso seja reformada a decisão recorrida, adotando a orientação do STJ, os autos serão conclusos ao $3^{\circ}$ VicePresidente e os recursos sobrestados serão automaticamente inadmitidos.

A Resolução dispõe ainda que a seleção dos recursos paradigmas e o sobrestamento dos recursos que lhe forem vinculados pressupõem a prévia análise do preenchimento dos requisitos formais e objetivos de admissibilidade recursal, caso contrário, em decisão fundamentada, proceder-se-á diretamente ao juízo de admissibilidade negativo.

Vamos exemplificar a questão: A parte $\mathrm{x}$ interpõe recurso especial em face de um acórdão proferido em sede de embargos de declaração opostos em face de uma decisão monocrática, que inadmitiu sua apelação com fulcro no Art. 557, do CPC, não esgotando a instância recursal, que deveria ser obtida com a interposição de um agravo inominado em face desta decisão monocrática, previsto no Art. 557, $\S 1^{\circ}$ do CPC. Ao analisar a 
admissibilidade do recurso, a $3^{\text {a }}$ Vice Presidência do TJRJ verificou que o mesmo se enquadrava nos moldes do Art. 543$\mathrm{C}$, do CPC, e o sobrestou, não sendo realizado o juízo de admissibilidade do recurso. Com isso a parte recorrida opôs embargos de declaração alegando que o referido recurso não merecia ser admitido, pois não havia esgotado a instância recursal. Em face disso, a $3^{\text {a }}$ Vice Presidência reconsiderou a decisão inadmitindo o recurso, seguindo o entendimento dado pelo Art. $5^{\circ}$ da Resolução 3 do TJRJ. A posição tomada pelo Tribunal de Justiça do Rio de Janeiro vai de encontro à posição tomada pelo STF nos casos de recurso extraordinário com repercussão geral, segundo o qual o Tribunal de origem não dever emitir juízo de admissibilidade sobre os recursos especiais já sobrestados, nem sobre os que venham a ser interpostos, até que o STJ decida os que tenham sido selecionados. 


\section{5 - ASPECTOS POLÊMICOS DA NOVA LEI E ANÁLISE JURISPRUDENCIAL}

No presente capítulo serão analisadas algumas questões polêmicas em torno da nova lei, além de uma breve análise jurisprudencial, para verificarmos como estão reagindo alguns dos Tribunais ao novo trâmite do recurso especial.

\section{1 - DA (IM)POSSIBILIDADE DE DESISTÊNCIA DO RECURSO PARADIGMA}

O Art. 501, do CPC, dispõe que o recorrente poderá, a qualquer tempo, sem a anuência do recorrido ou dos litisconsortes, desistir do recurso. Essa desistência, segundo o Art. 158 do $\mathrm{CPC}^{42}$, produzirá efeitos imediatamente, não necessitando de homologação judicial ou de concordância da outra parte. "É dizer: Não se pode, em princípio rejeitar a desistência, pois não se pede a desistência; simplesmente se desiste e a desistência produz efeitos imediatos." (Didier $\mathrm{Jr}$ e Cunha 2009)

Porém, o entendimento quanto ao recurso paradigma escolhido no trâmite da nova lei de recursos repetitivos tem sido diferente. Dizem Fredie Didier Jr. e Leonardo José Carneiro da Cunha:

\footnotetext{
"Quando se seleciona um dos recursos para julgamento, instaurase um novo procedimento. Esse procedimento incidental é instaurado por provocação oficial e não se confunde com o procedimento principal recursal, instaurado por provocação do recorrente. Passa, então, a haver, ao lado do recurso, um
}

\footnotetext{
42 "Art. 158. Os atos das partes, consistentes em declarações unilaterais ou bilaterais de vontade, produzem imediatamente a constituição, a modificação ou a extinção de direitos processuais."
} 
procedimento específico para julgamento e fixação da tese que irá repercutir relativamente a vários outros casos repetitivos. Quer dizer que surgem, paralelamente, dois procedimentos: a) o procedimento recursal, principal, destinado a resolver a questão individual do recorrente; $e, b)$ o procedimento incidental de definição de precedente ou da tese a ser adotada pelo Tribunal superior, que haverá de ser seguida pelos demais Tribunais e que repercutirá na análise dos demais recursos que estão sobrestados para julgamento. Este último procedimento tem uma feição coletiva, não devendo ser objeto de desistência, da mesma forma que não se admite a desistência em Ações Coletivas (Ação Civil Pública e Ação Direta de Inconstitucionalidade, por exemplo). O objeto desse incidente é a fixação de uma tese jurídica geral, semelhante ao de um processo coletivo em que se discutam direitos individuais homogêneos. Trata-se de um incidente com objeto litigioso coletivo." (Didier Jr e Cunha 2009)

O primeiro caso a ser julgado pela Corte Especial do STJ aconteceu nos recursos especiais 1.058 .114 e 1.063.343, que foram objeto do informativo $\mathrm{n}^{\circ} 0381$ do STJ:

\section{“RECURSO REPETITIVO. DESISTÊNCIA.}

A Corte Especial, ao prosseguir o julgamento, por maioria, entendeu que, submetido o recurso ao disposto na Resolução $n$. 8/2008-STJ e no Art. 543-C do CPC, na redação que lhe deu a Lei n. 11.672/2008 (recurso repetitivo), não há como ser deferido pedido de desistência. Admitiu-se que, quando submetido o recurso ao regime daquela legislação, surge o interesse público ditado pela necessidade de uma pronta Resolução da causa representativa de inúmeras outras, interesse esse que não se submete à vontade das partes. O Min. João Otávio de Noronha (vencido) entendia possível acolher a desistência, visto que é a lei quem a garante, além do fato de que a desistência, de acordo com a doutrina, é ato unilateral. Outros Ministros ficaram vencidos em parte, por entenderem diferir a análise da desistência para depois do julgamento da questão de direito tida por idêntica, garantindo, assim, a produção dos efeitos previstos no $\S 7^{\circ}$ do Art. 54 3-C do CPC, solução que, segundo essa linha, atenderia tanto ao interesse público quanto ao das partes. Dessarte, os autos retornaram à Segunda Seção para o julgamento do recurso repetitivo." (QO no REsp 1.063.343-RS, Rel. Min. Nancy Andrighi, julgada em 17/12/2008.)

Então a posição adotada pela Corte Especial do STJ foi no sentido de não deferir o pedido de desistência do recurso repetitivo, pois no momento em que foi admitido o recurso no 
regime da nova lei de recursos repetitivos surge um interesse público em resolver a questão paradigma, que está representando todos os recursos que possuem a idêntica questão de direito e que estão suspensos, aguardando o julgamento daquele recurso escolhido. Com isso, entenderam os Ministros da Corte Especial STJ que a desistência não poderia estar submetida a vontade das partes.

Porém, essa decisão não foi unânime, o Ministro João Otávio de Noronha, que teve seu voto vencido, entendia ser possível acolher a desistência, visto que a lei garante o pedido de desistência do recurso, argumentando ainda que a desistência, de acordo com a doutrina, é ato unilateral.

Outros Ministros ficaram vencidos em parte, por entenderem ser possível deferir a análise da desistência para depois do julgamento da questão de direito tida por idêntica, garantindo, assim, a produção dos efeitos previstos no $\S 7^{\circ}$ do Art. 543-C do CPC, solução que, segundo essa linha, atenderia tanto ao interesse público quanto ao das partes

Fredie Didier Jr. e Leonardo José Carneiro da Cunha entendem que a desistência, no caso, não afetaria o procedimento instaurado para a definição do precedente no STJ:

"Quando o recorrente, num caso como esse, desiste do recurso, a desistência deve atingir apenas, o procedimento recursal, não havendo como negar tal desistência, já que, como visto, ela produz efeitos imediatos, não dependendo de concordância da outra parte, nem de autorização ou homologação judicial. Ademais, a parte pode, realmente precisar da desistência para que se realize um acordo, ou se celebre um negócio jurídico, ou por qualquer outro motivo legítimo, que não necessita ser declinado ou justificado. Demais disso, o procedimento recursal é, como se sabe, orientado pelo princípio dispositivo.

Tal desistência, todavia, não atinge o segundo procedimento, instaurado para definição do precedente ou da tese a ser adotada pelo Tribunal superior." (Didier Jr e Cunha 2009) 
O STF já se deparou com a discussão sobre a possibilidade de a parte recorrente desistir do recurso que foi escolhido pelo Tribunal como o paradigma em caso de repercussão geral (Leal e Araújo 2009).

\begin{abstract}
"Petição/STF no 55.990/2008
DECISÃO

RECURSO EXTRAORDINÁRIO - DESISTENNCIA HOMOLOGAÇÃO.

1. Juntem.

2. Eis as informações prestadas pelo Gabinete:

Copersucar - Cooperativa de Produtores de Cana-de-açúcar, Açúcar e Álcool do Estado de São Paulo formula desistência do recurso extraordinário acima identificado. Sustenta que, quanto à alíquota de $5 \%$ do IPI sobre açúcar, está em discussão no processo apenas a ofensa ao princípio da seletividade, já havendo precedentes contrários em ambas as Turmas. Aponta a existência de outros extraordinários $-n^{o} s 441.298$ e 475.654, da relatoria de Vossa Excelência -, a versarem também sobre desvio de finalidade $e$ violação ao artigo 150, $\$ 6^{\circ}$, da Constituição Federal. Entende que a apreciação deste extraordinário poderá vir a causar-lhe prejuizos, ante a irrecorribilidade das decisões proferidas em repercussão geral e a possibilidade de o "leading case" gerar a inadmissão sumária dos recursos que tratem da mesma questão. Apresenta substabelecimento.

Em 18 de abril de 2008, Vossa Excelência pronunciou-se a favor da existência de repercussão geral. Não tendo ocorrido até esta data qualquer outra manifestação dos Ministros desta Corte. O prazo termina em 8 de maio próximo.

A subscritora da peça está regularmente credenciada no processo, contando com poderes especiais para desistir.

3. Ante o disposto no Regimento Interno desta Corte, homologo o pedido de desistência do recurso para que produza os efeitos legais. Insiram a notícia no sistema, considerado o prejuizo da repercussão geral.

4. Publiquem." (STF, RE 567.948/RS, Relator Ministro Marco Aurélio, Publicado em 20.05.2008) (Grifou-se)
\end{abstract}

Naquele caso, o Ministro relator homologou a desistência e na seqüência, a repercussão geral foi admitida num outro recurso extraordinário, sem prejuízo à racionalidade que busca o Poder Judiciário. (Leal e Araújo 2009)

Com isso, concluem Saul Tourinho Leal e Vicente Coelho Araújo que: 
"Logo, o que se propõe é que o STJ retome o debate acerca do tema e leve em consideração a possibilidade de a parte desistir do recurso escolhido para ser o paradigma na sistemática dos recursos repetitivos. Homologada a desistência, outro recurso mais adequado à solução da controvérsia deverá ser escolhido, e dessa forma ter-se-á deferência tanto às regras de direito processual como às necessárias celeridade e eficiência na prestação jurisdicional, prestigiando-se o interesse público." (Leal e Araújo 2009)

Esse, por certo, seria o melhor entendimento a ser adotado. Pois, aquele recurso escolhido para ser o paradigma não pode ser insubstituível, já que é um recurso que foi selecionado dentre muitos outros que possuíam idêntica questão de direito. Com isso, deveria ser homologada a desistência do recurso paradigma, substituindo-se o mesmo por outro recurso.

\section{2 - INCONSTITUCIONALIDADE DA LEI №. 11.672/08?}

Os debates sobre a lei também se estendem a sua constitucionalidade. Diz Cássio Scarpinella Bueno:

"A análise dos dispositivos colocados em destaque faz trazer à tona a questão concernente à constitucionalidade das regras relativas ao trato dos 'recursos especiais repetitivos'. Estariam elas violando o 'modelo constitucional do direito processual civil', emprestando às decisões do Superior Tribunal de Justiça verdadeiro efeito vinculante? Estaria a lei modificando, ainda que de forma discreta, as hipóteses de cabimento do recurso especial $e$, mais do que isso, o órgão competente para seu julgamento? As respostas a estas questões são, no entender deste Curso, positivas, porque as modificações foram introduzidas sem prévia (e indispensável) aprovação da proposta de Emenda à Constituição n. 358/2005, ainda em trâmite perante a Câmara dos Deputados, que, ao propor diversas modificações no Art. 105 da Constituição Federal, introduz um $\$ 3^{\circ}$ naquele dispositivo segundo o qual: 'A lei estabelecerá os casos de inadmissibilidade do Recurso Especial'” (Bueno 2008, P. 276)

Já Eduardo Talamini acredita que:

"O julgamento por amostragem, desde que aplicado em seus devidos limites e com a observância das cautelas e garantias aqui 
brevemente destacadas, não parece ofender os princípios constitucionais do processo nem as regras sobre competência recursal do Superior Tribunal de Justiça. Trata-se de racionalizar a atividade do STJ, na esteira do que também se procurou fazer com o STF, precisamente em casos que já vinham recebendo decisões homogêneas, meramente reiterativas. $E$ a institucionalização desse procedimento inclusive possibilita seu controle de modo mais eficiente.

(...)

O fundamental é que se observem os limites postos na lei: cabe apenas o sobrestamento dos recursos que versem sobre idêntica questão de direito - e apenas a eles será aplicável aquilo que for decidido no julgamento do recurso amostra. Tudo o que ultrapassar essa fronteira será indevido $-e$ passível de impugnação recursal,(...)." (Talamini 2008)

Esse é o melhor posicionamento.

Cassio Scarpinella, que considera a lei inconstitucional, alega que deveria o STJ aguardar a aprovação da Emenda Constitucional $n^{\circ}$. 358/2005, que insere o $\S 3^{\circ}$ no Art. 105 da Constituição Federal, que dispõe que a lei estabelecerá os casos de inadmissibilidade do recurso especial. Porém, no caso não estamos tratando de admissibilidade do recurso, mas sim do julgamento do mérito de recursos especiais com questões de direito repetitivas.

Com isso, entendemos que a lei é constitucional, porém deve a mesma ser aplicada em seus devidos limites, assegurando sempre as partes o devido processo legal, contraditório e a ampla defesa, para que dessa forma possamos garantir a celeridade processual e a qualidade das decisões que desejamos do nosso judiciário.

\section{3 - O RECURSO ESPECIAL REPETITIVO E AS AÇÕES COLETIVAS}

É interessante pensarmos também nos efeitos da nova lei de recursos repetitivos com relação aos processos coletivos. 
Seria a Lei 11.672/08 aplicável a esses processos? Sim. Os processos coletivos também estão sujeitos ao procedimento do art. 543-C, do CPC, caso haja multiplicidade de recursos com idêntica questão de direito.

Em relação a esse tema, Luiz Rodrigues Wambier e Rita de Cássia Vasconcelos trazem questionamentos interessantes:

\begin{abstract}
"Em primeiro lugar, indaga-se se deveriam os recursos especiais interpostos em face de acórdãos proferidos em açôes coletivas, serem, somente por tal circunstância, selecionados para julgamento pelo STJ. A resposta para nós, é negativa. A situação de que ora se trata é diferente da regulada pelo Art. 543-B, do CPC, que dispõe sobre o requisito da repercussão geral da questão constitucional nos recursos extraordinários. Em relação a repercussão geral, um dos autores desse texto já defendeu que esse requisito deve ser pressuposto nas ações coletivas pelo simples fato de serem coletivas. Os recursos especiais, diferentemente, não deverão ser relacionados simplesmente porque contidos em demandas de natureza coletiva, mas, tão somente, quando realmente 'representativos da controvérsia', nos termos da nova lei." (Wambier e Vasconcelos 2008, P. 44)
\end{abstract}

Com isso, entendemos que o fato do processo ser coletivo, por si só não enseja sua escolha para que seja o representativo da controvérsia. Porém, no caso de termos uma questão de direito repetitiva a ser julgada pelo STJ, em que temos processos individuais e coletivos, deveria ser escolhido pelo menos um de cada como representantes da controvérsia, para que se possa ter uma maior diversidade de argumentos e fundamentos para julgar o conflito.

Os referidos autores demonstram, ainda, preocupação com relação à regra do Art. $1^{\circ}, \S 2^{\circ}$, da Resolução $n^{\circ}$. 8/2008, do STJ, que dispõe que o agrupamento de recursos repetitivos levará em consideração apenas a questão central discutida, sempre que o exame desta possa tornar prejudicada a análise de outras questões argüidas no mesmo recurso: 
"A solução para essa questão parece estar no próprio dispositivo acima transcrito. A contrario sensu, não se deve levar em consideração apenas a questão central discutida, se o exame desta não tornar prejudicada a análise de outras questões argüidas no mesmo recurso. Assim, deve-se levar em conta, para a escolha do recurso especial a ser encaminhado ao STJ, se de ações coletivas se estiver tratando, os argumentos e fundamentos relativos às questões processuais (até porque a questão central discutida poderá ser de natureza processual, como por exemplo, a que diz respeito à legitimidade do proponente da ação coletiva) que estejam presentes concomitantemente com a questão central discutida (se, repita-se, a questão central não for de natureza processual), pois invariavelmente relevantes (...).

Precisamente por isso, pensamos que o sobrestamento do recurso interposto em ações individuais não deverá atingir automaticamente todas as ações coletivas que tratem da mesma questão de direito." (Wambier e Vasconcelos 2008 P., 45)

Com isso, deveria haver a escolha ou afetação de recursos especiais, levando-se em conta as peculiaridades das questões nele versadas, dizem os autores.

Além disso, com relação à intervenção de terceiros prevista no Art. 543-C, $\S 4^{\circ}$, do CPC, Luiz Rodrigues Wambier e Rita de Cássia Corrêa de Vasconcelos, entendem que no caso dos processos coletivos a mesma não deve ser restringida, pois nas ações coletivas há uma peculiaridade com relação aos legitimados a propor as mesmas. (Wambier e Vasconcelos 2008, P. 45).

Porém, acreditamos que para haver a intervenção de terceiros, deve ser demonstrada pertinência temática. Se não houver nenhuma restrição às intervenções, o procedimento célere dos recursos repetitivos poderá ficar inócuo, pois o número elevado de intervenientes dificultará a análise de todas as manifestações, atrapalhando o julgamento do processo, ao invés de ajudar. 


\section{6 - CONCLUSÃO}

A análise deste trabalho foi feita com base em um novo instituto, a Lei $\mathrm{n}^{\circ}$. 11.672/08, que adicionou o art. 543-C ao CPC, que tem como objetivo reduzir a subida de recursos idênticos que lotam os gabinetes dos ministros do STJ e obstam a análise de questões de maior interesse da sociedade.

Os recursos especiais singulares, continuarão seguindo o modelo antigo previsto no CPC, porém quando houver multiplicidade de recursos especiais com fundamento em idêntica questão de direito, o rito a ser seguido será o do art. 543-C, do CPC.

Embora haja críticas sobre a nova lei de recursos repetitivos, esta é uma tentativa de livrar o STJ de um colapso. O número de recursos especiais estava crescendo cada vez mais a cada ano. Os recursos ficavam anos conclusos aguardando sua decisão.

A lei de recursos repetitivos pode não ser perfeita, mas é de se considerar que tem gerado muitos resultados positivos do ponto de vista da celeridade processual e da razoável duração do processo. Conforme dados do $\mathrm{STJ}^{43}$, a redução de demandas no âmbito do referido Tribunal Superior entre os meses de Janeiro a Abril de 2009 foi de 40,6\% em relação ao ano passado.

A referida lei, se aplicada dentro dos moldes previstos, não ofende o princípio do contraditório e da ampla defesa, pois possui os seus meios próprios para impugnação das decisões.

\footnotetext{
${ }^{43}$ Matéria Publicada no Jornal "O Globo" em 25.05.09, página 4, Caderno O País
} 
A matéria ainda deve ser amadurecida e com o julgamento dos recursos nos moldes dessa lei serão solucionadas as dúvidas com relação à aplicação de determinados dispositivos. 


\section{BIBLIOGRAFIA}

BITTAR, Eduardo C. B. Metodologia da Pesquisa. $7^{\text {a }}$ Edição. São Paulo: Saraiva, 2009.

BRASIL. Constituição da República Federativa do Brasil.

BRASIL. Lei Federal $n^{o}$. 5.869/73 - Institui o Código de Processo Civil.

BRASIL. Lei Federal $n^{o} .11 .672$ de 08 de maio de 2008 Acresce o art. 543-C à Lei no 5.869, de 11 de janeiro de 1973 Código de Processo Civil, estabelecendo o procedimento para o julgamento de recursos repetitivos no âmbito do Superior Tribunal de Justiça.

BUENO, Cassio Scarpinella. Curso sistematizado de direito processual civil: recursos, processos e incidentes nos tribunais, sucedâneos recursais: técnicas de controle das decisões jurisdicionais. 1 ${ }^{a}$ Edição. Vol. 5. São Paulo: Saraiva, 2008.

CÂMARA, Alexandre Freitas. Lições de Direito Processual Civil. 16 ${ }^{\text {a }}$ Edição. Vol. 2. Rio de Janeiro: Lumen Júris, 2008.

CÂMARA DOS DEPUTADOS. Exposição de Motivos da Lei 11.672/2008. Disponível em

http://www.camara.gov.br/sileg/integras/465291.pdf.

Acesso em 04 de junho de 2009.

DIDIER JR., Fredie, e Leonardo José Carneiro da Cunha. Curso de Direito Processual Civil - Meios de Impugnação às decisões judiciais e processo nos tribunais. $7^{\text {a }}$ Edição. Vol. 3. Salvador: Jus Podivm, 2009.

ETCHEVERRY, Carlos Alberto. "Jus Navigandi." STJ: a súmula vinculante por via oblíqua. 30 de julho de 2008. http://jus2.uol.com.br/doutrina/texto.asp?id=11552 (acesso em 11 de maio de 2009). 
LEAL, Saul Tourinho, e Vicente Coelho Araújo. "Migalhas." Os recursos repetitivos no STJ e o direito da parte à desistência do recurso paradigma. 9 de fevereiro de 2009. http://www.migalhas.com.br/mostra_noticia_articuladas.aspx?c od=77894 (acesso em 12 de maio de 2009).

NOGUEIRA, Daniel Moura. "A nova sistemática do processamento e julgamento do recurso especial repetitivo, Art. 543-C, do CPC." Revista de Processo (Revista dos Tribunais) v. 164 (2008): 235-244.

POMAR, João Moreno. "Jus Navigandi." Remendo na regulamentação da Lei $n^{\circ} 11.672 / 08$ (Resolução STJ $n^{\circ}$ 08/08). 04 de novembro de 2008.

http://jus2.uol.com.br/doutrina/texto.asp?id=11929 (acesso em 11 de maio de 2009).

SERAU JÚNIOR, Marco Aurélio; REIS, Silas Mendes dos. Recursos Especiais Repetitivos no STJ. São Paulo: Método, 2009.

SOUZA, Roberto Carvalho de. Recurso Especial. Rio de Janeiro: Forense, 1997.

STF. RE 567.948/RS, Relator Ministro Marco Aurélio, Publicado em 20.05.2008

STF. Regimento Interno do Supremo Tribunal Federal - RISTF. STJ. AgRg no Ag 778.950/RS, Rel. Ministro Luiz Fux, PRIMEIRA TURMA, julgado em 10/04/2007, DJ 07/05/2007.

STJ. AgRg na MC 15.112/RJ, Rel. Ministro Fernando Gonçalves, Quarta Turma, julgado em 02/04/2009, DJe 20/04/2009.

STJ. AgRg no RECURSO ESPECIAL No $\mathrm{N}^{\circ} 1.100 .286 / \mathrm{RS}$ (2008/0232432-5) Relator Ministro Humberto Gomes Martins. STJ. Regimento Interno do Superior Tribunal de Justiça RISTJ. 
STJ. QO no REsp 1.063.343-RS, Rel. Min. Nancy Andrighi, julgada em 17/12/2008.

STJ. REsp $\mathrm{n}^{\circ}$. 950.884/MG, Ministro Humberto Martins, Publicado em 08.05.2009.

STJ. Resolução nº. 7/2008.

STJ. Resolução Nº. 8/2008.

TALAMINI, Eduardo. "Julgamento de recursos no STJ 'por amostragem,". Informativo Justen, Pereira, Oliveira e Talamini. 14 de Abril de 2008. http://www.justen.com.br/informativo (acesso em 11 de Fevereiro de 2009).

TAVARES JUNIOR, Homero Francisco. "Recursos especiais repetitivos: aspectos da Lei 11.672/2008 e da Res. 8/2008 do STJ." Revista de Processo (Revista dos Tribunais) v. 166 (2009): 190-202.

THEODORO JÚNIOR, Humberto. Curso de Direito Processual Civil - Teoria Geral do Direito Processual Civil e Processo de Conhecimento. 45 adição. Vol. 1. Rio de Janeiro: Forense, 2006.

TRIBUNAL DE JUSTIÇA DO ESTADO DO RIO DE JANEIRO. RESOLUÇÃO TJ $3^{\mathrm{a}}$ VICE-PRESIDÊNCIA, $\quad \mathrm{N}^{\mathrm{o}} 3$, de 05/05/2009.

TRIBUNAL DE JUSTIÇA DO ESTADO DO RIO DE JANEIRO. Código de Organização e Divisão Judiciária do Estado do Rio de Janeiro - CODJERJ.

TRF - SEgundA REgião. Apelação Cível nº 385889 , Processo 200351010258760 - RJ, Quarta Turma Especializada, Data da decisão: 25/11/2008

WAMBIER, Luiz Rodrigues; VASCONCELOS, Rita de Cássia Corrêa de. "Recursos especiais repetitivos: reflexos das novas regras (Lei 11.672/2008 e Resolução 8 do STJ) nos processos 
coletivos." Revista de Processo (Revista dos Tribunais) Volume 163 (2008): 29-49.

WAMBIER, Teresa Arruda Alvim. Recurso Especial, Recurso Extraordinário e Ação Rescisória. São Paulo: Revista dos Tribunais, 2008.

WAMBIER, Teresa Arruda Alvim; MEDINA, José Miguel Garcia. "Sobre o novo Art. 543-C do CPC: sobrestamento de recursos especiais "com fundamento em idêntica questão de direito". Revista de Processo (Revista dos Tribunais) Volume 159 (2008): 215-221. 


\section{ANEXO}

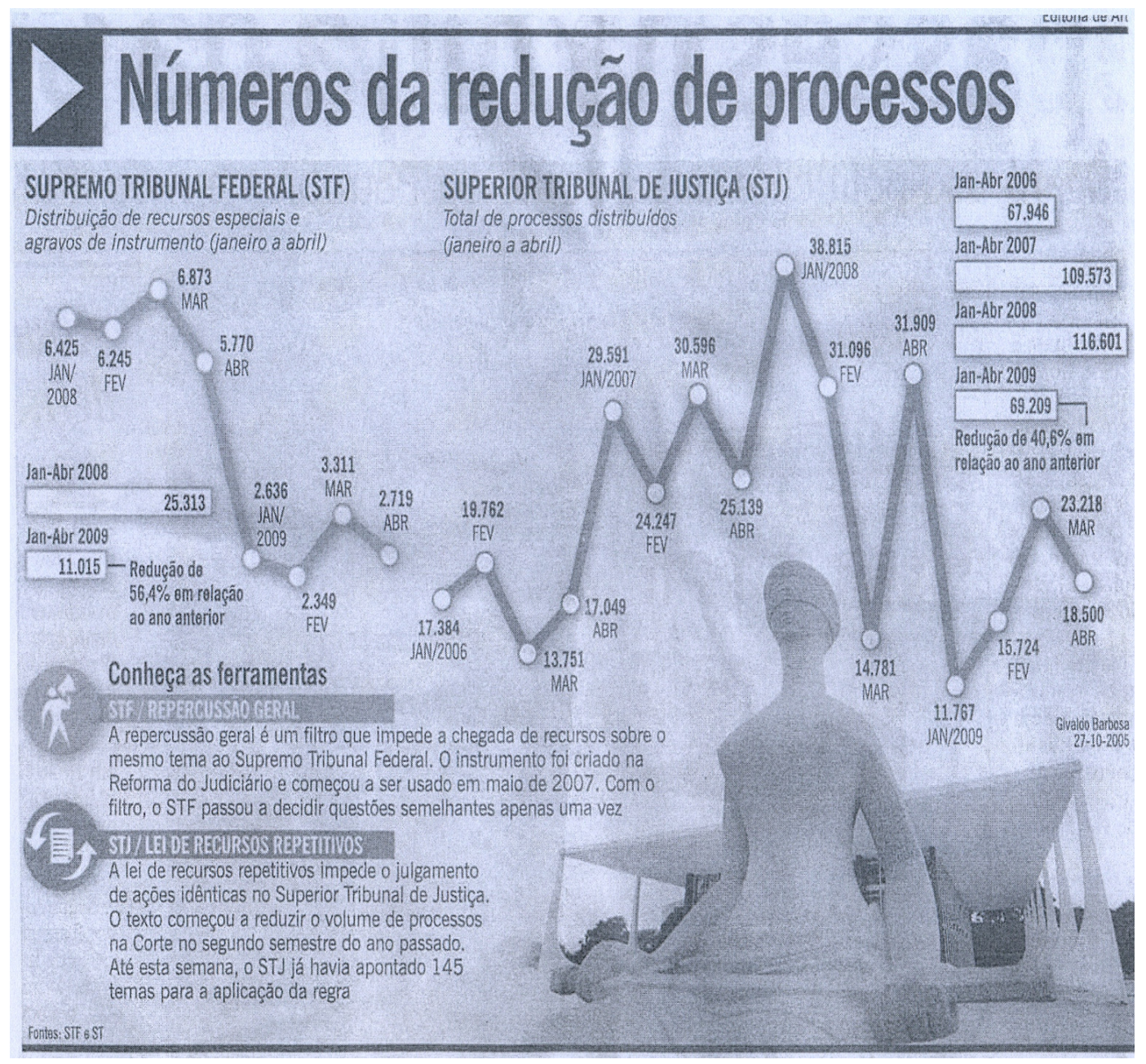

Matéria Publicada no Jornal "O Globo" em 25.05.09, página 4, Caderno O País 


$$
\text { Pontifícia Universidade Católica }
$$

\section{NORMAS PARA ELABORAÇÃO E APRESENTAÇÃO DA MONOGRAFIA JUR 1919}

\section{ANEXO II}

A Monografia deve ser entregue até o dia 4 de junho de 2009.

A presente Monografia, apresentada pelo(a) aluno(a) NATÁLIA AGUIAR COKLHO VALGODE poderá ser submetida à exposição e defesa perante a Banca Examinadora designada pelo Departamento de Direito da PUC-Rio.

Rio de Janeiro, o4 de yunens de 2009.

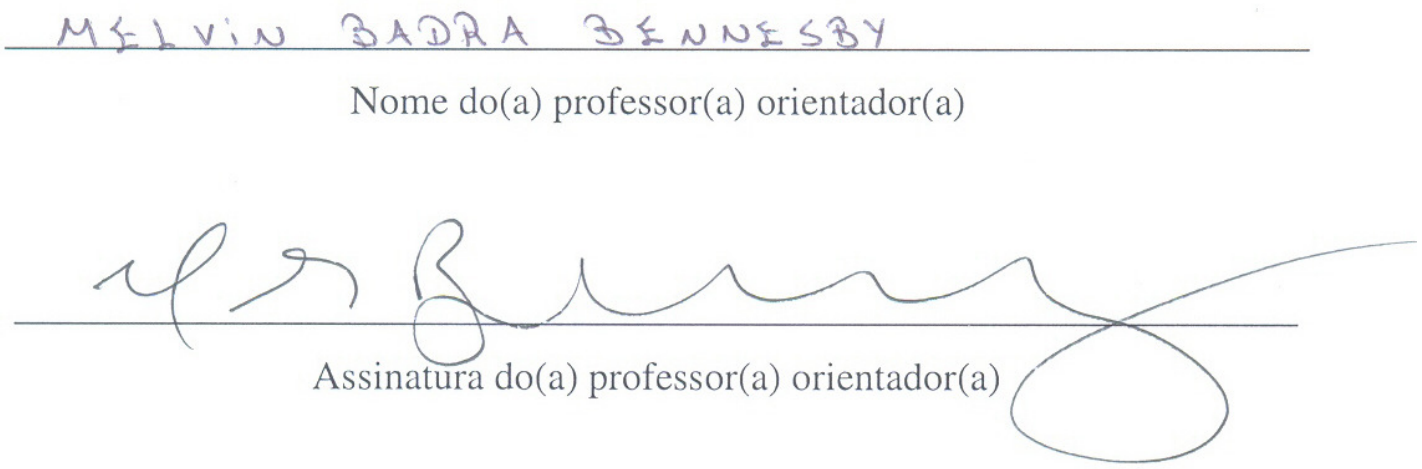

$\mathrm{O}(\mathrm{A})$ autor(a) deste trabalho autoriza o Departamento de Direito da PUC-Rio a divulgálo, no todo ou em parte, resguardados os direitos autorais conforme legislação vigente. Rio de Janeiro, o4 de junno 2009.

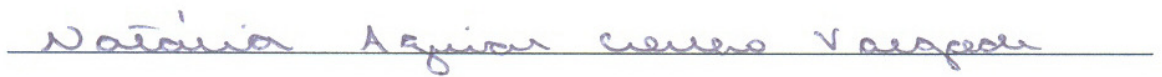

Assinatura do(a) aluno(a) 